\title{
Divergent Development: The Pursuit of Liberty, Equality, and Growth in Argentina and the Republic of Korea*
}

\author{
by \\ Lawrence R. Alschuler \\ Department of Political Science \\ University of Ottawa \\ Ottawa, Ontario \\ Canada K1n 6 N5
}

\section{v. $2 / 12 / 97$ \\ C 1997 Lawrence R. Alschuler}

Cite: Alschuler, Lawrence R. (1997). "Divergent Development: The Pursuit of Liberty, Equality, and Growth in Argentina and the Republic of Korea." Journal of WorldSystems Research 3: 115 - 207.

*This article was first presented as a paper at the 8th International Conference on SocioEconomics, Session on "Comparative Political Economy: Contemporary and Islamic Perspectives", held at the University of Geneva, Switzerland, July 12-14, 1996.

Divergence in the development of East Asian and Latin America NICs is catching the attention of a growing number of political economists. This divergent development has sparked debates over theory between advocates of neo-liberal and neo-dependency approaches (Biersteker; Stallings: 370 ) in accounting for the regional divergence: does the East Asian success confirm modernization theory (neo-liberalism) generally, or does each region require its own theory? (See Barrett and Whyte on Taiwan; Alschuler: chap. 4 and Lanzarotti: chap. 5 on Korea; Evans, 1987). East Asian "miracles" have led to equally bitter controversies over practice with regard to policy recommendations for third world nations: is the East Asian model exportable and is this desirable? (see Amsden; Fishlow; Broad and Cavanagh).

[Page 115]

Journal of World-Systems Research

In addressing these issues I propose to account for the divergence between the NICs of these two regions through a comparative analysis of a member state from each region, Argentina and the Republic of Korea. By accounting for, that is explaining and predicting, the divergent development of these two nations, we will have a basis for asserting which theoretical approach (neo-dependency or neo-liberalism) is more valid. And once their divergent development is explained, we will be able to identify the conditions responsible for the success of the East Asian model and to say whether these same conditions may be found elsewhere allowing for the successful export of that model. 
Though much of the research on divergent development focuses on "econ omic growth" or "economic development", if we are to express a preference for either the East Asian or the Latin American model we will require a broader definition of development. The following labels suggest trade-offs between aspects of a broader notion of development: authoritarian growth, development with(out) equity, growth without development. Under what circumstances, indeed applying which model, would growth, liberty, and equality be compatible? We include these three aspects of development in our definition so that we may assess the desirability of one model over another.

[Page 116]

Journal of World-Systems Research

The trail for this research has been blazed by Gereffi and Wyman in Manufacturing Miracles and by Haggard in Pathways from the Periphery. These political economists make inter-regional comparisons of NICs from Latin America and East Asia. In order to build on their research we need to understand first, how they have structured the discussion and second, what questions they have left un answered. The research on divergent development has been structured around five main topics:

1. the conditions underlying the choice of development strategy at the end of the first stage of import substitution (Stallings: 365; Haggard),

2. the conditions for the effectiveness of state intervention to formulate and implement development strategies (Jenkins),

3. the conditions of the world economy impinging on the success of development strategies (Stallings: chap. 1),

4. the responsibility of development strategies for successes and failures (Gereffi and Wyman),

5. the conditions behind the compatibilities and incompatibilities between aspects of development: growth, equality, and liberty (Alschuler: chap. 5; Stallings: 3, 350).

[Page 117]

Journal of World-Systems Research

Previous research has been uneven in its treatment of these five topics. For example, Haggard (chaps. 9, 10) has documented convincingly topic 1 and has opened a fruitful discussion of topic 5. Many authors in the volume edited by Gereffi and Wyman emphasize topics 1,2 , and 4, though they treat topics 3 and 5 more briefly. My impression of these and other key studies of divergent development (Ranis and Orrock; 
Anglade and Fortin; Jenkins) is that topic 1 is already researched adequately, that topic 2 offers serious alternative explanations which have not yet been tested, that topic 3 has not been researched adequately, that topic 4 seems to be taken for granted without adequate testing, and that topic 5 remains at the stage of compelling questions without answers.

The present study builds on the previous research and addresses the limitations noted in the five topics by extending my work in comparative political economy on alternative development strategies in Korea and Argentina (Alschuler). More specifically, my work has a theoretical framework that already encompasses the influence of development strategies (topic 4), of multinational corporations and dependency relations (topic 3 ), and of capital accumulation on the three aspects of development: liberty, growth, and equality (topic 5). This framework has been refined and extended to include the impact of external shocks from the world economy (topic 3 ) and the influence of state effectiveness (topic 2). Furthermore, I have formulated a new method suitable for the testing of theory-based predictions about divergent development. This method of qualitative causal path analysis will allow us to overcome a further limitation of recent research, namely the insufficient testing of the contending theoretical approaches each claiming to account for divergent development.

[Page 118]

Journal of World-Systems Research

This paper begins with the theoretical formulations and ends with the results of the empirical tests. The first section, "The Model", presents a set of causal propositions to explain developmental change. After offering a revised "dependency sub-model", an "interventionist sub-model" describes the policies belonging to each development strategy and links them to developmental change. Concluding this section is a set of propositions on the influence of state effectiveness and external shocks on development.

In the second section, "The Methods", we introduce a method, called "qualitative causal path analysis", for formulating testable predictions about development. We also make explicit our research strategy.

In the third section, "The Cases", we summarize the main historical periods in the political economy of Argentina and Korea since the 1960s. The summaries provide a context for the specific policies, external shocks, and levels of state effectiveness that form the basis for our predictions of developmental change. The section ends with the predictions, formulated according to our qualitative causal path technique and using the table of policy values.

[Page 119]

Journal of World-Systems Research 
In the fourth section we present the results of the empirical tests. In the concluding section we discuss the role of development strategies, external shocks, and state effectiveness in the explanation of divergent development. Also on the basis of the results we comment on the debates over the theory and practice of development.

\section{THE MODEL}

Our propositions on development are interrelated within a causal model, a revision of the one in Alschuler (1988). The model contains five groups of variables, including development. The broader concept of development has three aspects: growth (the economic aspect), equality (the social aspect), and liberty (the political aspect). In the pursuit of development there may be trade-offs between these aspects, making it a challenge to promote growth, equality, and liberty simultaneously. One aim of our research is to reveal the conditions under which these aspects of development are compatible and incompatible. Three versions of the model are required to explain the three different and semi-autonomous aspects of development.

The five groups of variables in the model include development, multinational presence, dependence, capital accumulation, and state intervention. The first four groups make up a "dependency sub-model" while the last is an "interventionist sub-model". We begin by defining the variables and their causal relationships in the "dependency sub-model".

[Page 120]

Joumal of World-Systems Research

\section{The Dependency Sub-Model}

\section{Development}

The broad meaning of development is founded on the idea of personal growth, itself defined in terms of humanization, conscientisation, and individuation. The broad definition then includes those societal conditions that promote personal growth (Galtung et al.): economic growth, equality in the distribution of wealth, and political liberty. Economic growth as commonly understood is the increase in the production of wealth in society. Our indicator, in common use, is the rate of change in the gross domestic product per capita.

The degree of equality in the distribution of wealth may be analysed along a number of national dimensions: urban-rural, labor-capital, and along intra-class dimensions: largesmall industries, large-small farms, skilled-unskilled labor. We adopt only one dimension, labor-capital in manufacturing. Our indicator for the degree of equality in the distribution of income between labor and capital is the ratio of the real wage index to the productivity index in manufacturing. Many authors support the validity of this indicator 
in both Korea and Argentina (Wontack Hong: 30; Hagen Koo; W.C. Smith: 30; Mallon and Sourrouille: 117; Peralta-Ramos: 61-62; Hasan and Rao: 35, 199; Shafer: 127).

[Page 121]

Journal of World-Systems Research

Liberty is an essential element of democracy, along with a state executive accountable to an elected parliament and regular, fair elections (Rueschemeyer and Evans). More specifically, liberty includes both political rights and civil liberties. Expert ratings of both aspects over time for Korea and Argentina serve as our indicator (Gurr; Gastil).

\section{Multinational presence}

This variable reflects the qualitative aspect of foreign direct investment rather than its quantity. Qualitatively, multinational presence in industry takes the form of either investment in manufacturing branch plants or in manufacturing export platforms. A branch plant is a subsidiary which manufactures in the host country in order to sell in the local market. An export platform is a subsidiary which employs unskilled, low-wage labor to produce manufactured goods for export to core country markets. "High" signifies a predominance of branch plants over export platforms. "Low" means the opposite tendency.

\section{Dependence}

The coherence of this group of conditions stems from the following definition: "Dependence is a situation in which an asymmetrical exchange between nations reinforces the power of one (the dominant) nation and inhibits the self-reliance of the other (dependent) nation (Alschuler: 16). Each of the many kinds of exchange may be characterized by more or less dependence. Those kinds include trade, technology, capital, food, and debt. Trade dependence, for instance, is high when, due to deteriorating terms of trade, the volume of raw material exports must continually increase in order to import a constant volume of manufactured goods. Debt dependence is high when, due to rising interest rates and appreciation of the dollar, new international loans are required in order to continue debt service payments on past loans. Technological dependence is high when the royalty payments on imported techonology reduce resources available for local research and development, inhibiting technological self-reliance. Food dependence is high when the payment for food imports to meet minimum caloric standards derives from the exports of agricultural cash crops, further shifting land use away from subsistence crops. Capital dependence is high when new inflows of foreign investment are needed to compensate for the outflows of profit repatriation and the asymmetrical transfer payments between subsidiaries and the head office of multinational firms.

[Page 122]

Journal of World-Systems Research 


\section{Capital accumulation}

Within this group are those conditions which contribute directly to capital formation. One sub-group is the reserves of foreign exchange or hard currency. These reserves permit the import of technology, raw materials, intermediate and capital goods required for the expansion of industry. A second sub-group contains two conditions of the industrial process: the degree of capital intensity and the degree of industrial concentration. The factor mix of labor and capital influences directly the accumulation of capital. Modern technology combines with skilled labor to enhance productivity and higher profit rates for reinvestment. Generally, high capital intensity accompanies industrial concentration, meaning the share of the market controlled by a small number of firms, the top ten, for example. Concentration contributes to accumulation through economies of scale which permit large reinvestable profits. Smaller, labor-intensive firms also contribute to capital accumulation through low wages to unskilled labor and low technology costs which permit reinvestable profits. These two alternatives mark important contrasts between the East Asian and the Latin American approaches to development.

Between these four groups of variables there are eleven causal relations that constitute the dependency sub-model. In formulating this sub-model we specify the sign and direction of each causal relation. Dependency theory, as revised during the $1980 \mathrm{~s}$, is the basis for the causal propositions linking multinational presence, dependence, capital accumulation, and development (Cardoso; Evans: 1979; Alschuler). Each causal proposition corresponds to the dependency literature and has been supported by empirical research. The propositions 6 through 10 apply to all three aspects of development both in East Asia and Latin America. Proposition 11 is modified depending on the aspect of development and the region (see "the methods" section on causal complexity and conjunctural causation). This means that the conditions promoting growth may not be compatible with the conditions for equality or liberty. We should keep in mind that we are formulating a general model for East Asia and Latin America, even though we are applying the model to Korea and Argentina.

[Page 123]

Journal of World-Systems Research

LINK 6. The more multinational presence takes the form of branch plants, the greater the capital intensity and industrial concentration.

LINK 7. The more multinational presence takes the form of branch plants, the greater the dependence.

LINK 8. The greater the dependence, the less the foreign exchange reserves. 
$L I N K$ 9. The greater the dependence, the greater the capital intensity and industrial concentration.

LINK 10. The greater the foreign exchange reserves, the greater the economic growth, the greater the equality, and the greater the liberty (all three aspects of development).

LINK 11. (EQUALITY) The greater the capital intensity and industrial concentration, the less the equality (between capital and labor).

LINK 11. (LIBERTY IN LATIN AMERICA) The greater the capital intensity and industrial concentration, the less the liberty.

LINK 11. (LIBERTY IN EAST ASIA) The greater the capital intensity and industrial concentration, the greater the liberty.

LINK 11. (GROWTH IN LATIN AMERICA) The greater the capital intensity and industrial concentration, the greater the economic growth.

LINK 11. (GROWTH IN EAST ASIA) The greater the capital intensity and industrial concentration, the less the economic growth.

[Page 124]

Journal of World-Systems Research

What are the implications of the five versions of causal link 11 taken together? What are the trade-offs between the three aspects of development as incorporated into the model?

a. In Latin America, where capital intensity sustains capital accumulation, growth tends to be incompatible with liberty and equality. Sectoral conflicts in Argentina are known to revolve around the trade-off between capital accumulation and income distribution. On the one hand, repressive regimes pursue growth at a social cost to labor or on the other hand democratic regimes improve labor conditions at the cost of slower growth.

b. In East Asia, where labor intensity sustains capital accumulation, growth tends to be compatible with equality but incompatible with liberty. Korea has a reputation for authoritarian growth while maintaining a high degree of income equality, judged by international standards.

[Page 125]

Journal of World-Systems Research 


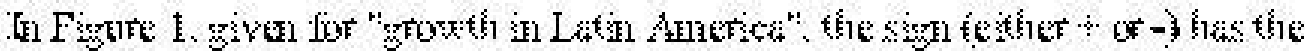

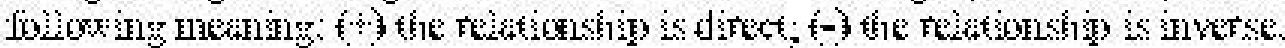

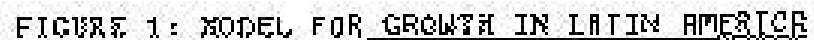

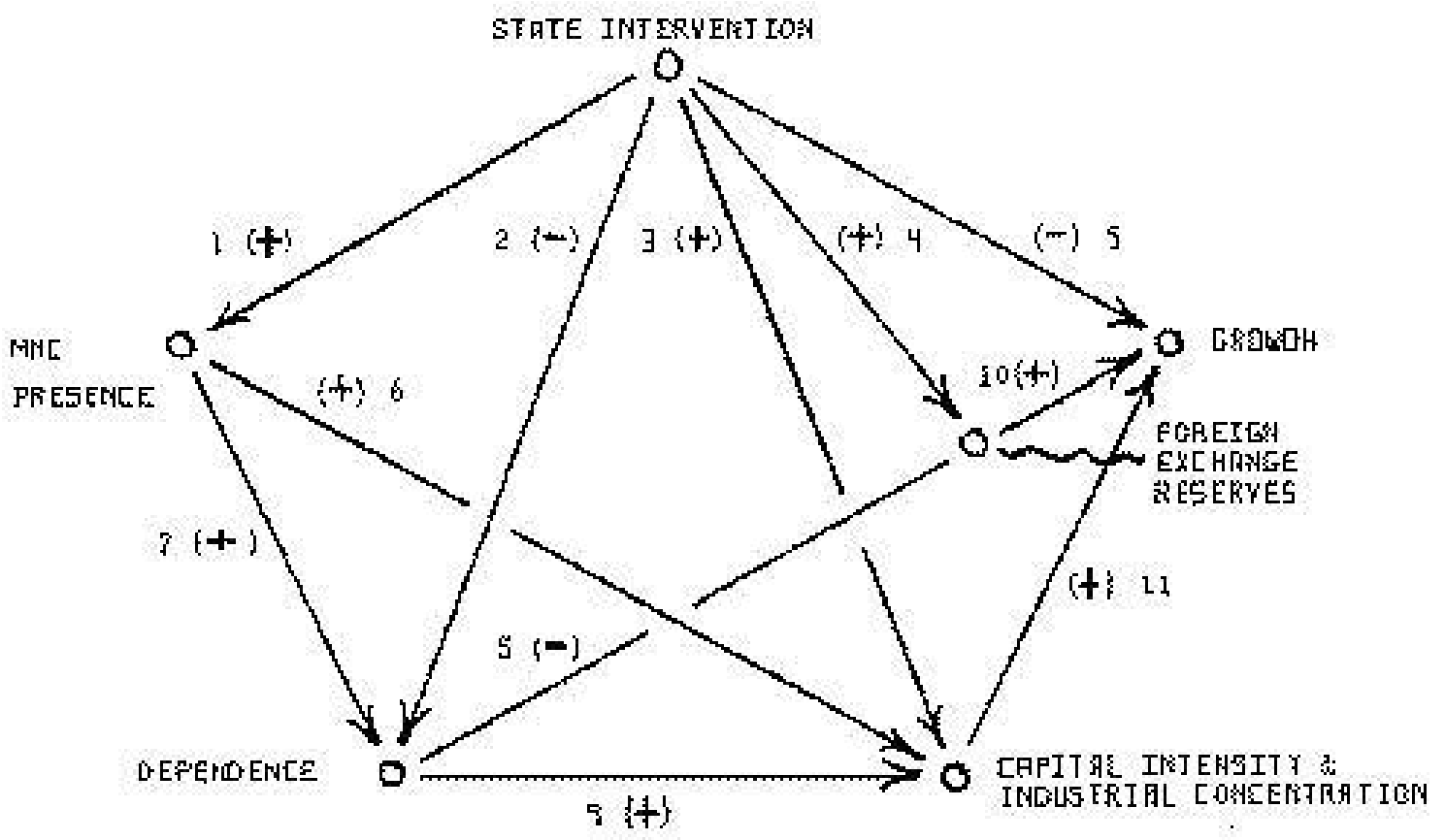

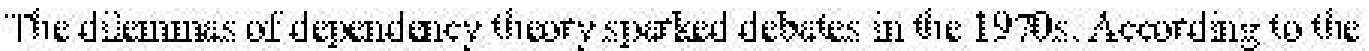

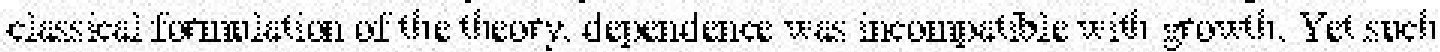

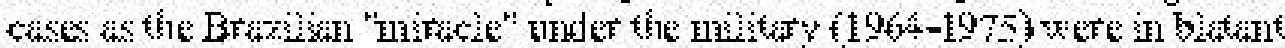

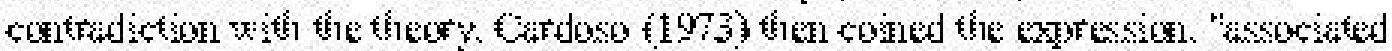

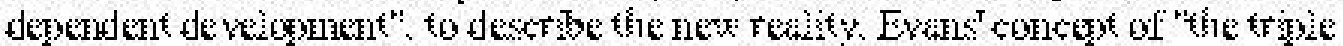

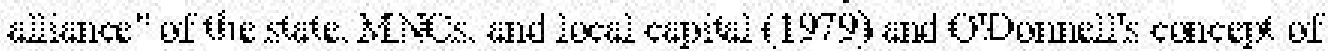

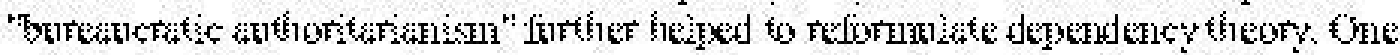

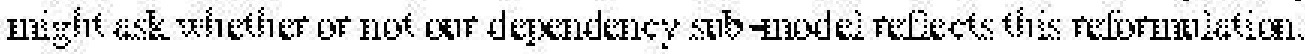

\section{(1) 126}

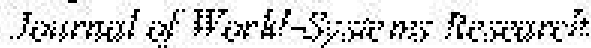


The sub-model includes two different and possibly opposite influences of dependence on growth. Links 8-10 and 9-11 can be contradictory, one promoting and the other impeding growth. In accordance with classical dependency theory, capital and technological dependence reduce foreign exchange reserves (due to profit repatriation and royalty payments), reducing growth. Yet, in accordance with the revised theory, these forms of dependence also increase capital intensity (due to technology transfer and fresh investment in manufacturing firms), increasing growth. While the sub-model includes both relations, the predominance of one over the other depends on the quantity of multinational investment.

Bornschier and Chase-Dunn $(83,94)$ make the important distinction between the accumulated stock and the annual flow of foreign direct investment. Their research findings indicate that the stock has a long term negative impact on growth, while the flow has a short term positive impact on growth. They also suggest that the positive impact of continuing inflows of FDI tends to mask the negative impact of large stock. The Brazilian "miracle" illustrates this. When the inflows of FDI slowed after 1975, the negative impact of the large foreign capital stock predominated, resulting in the reduced growth rate and the end of the "miracle". Our model incorporates this dependency dynamic in the following way. As long as there are continuing inflows of FDI, the positive impact will predominate (path 9-11). When the inflows slow or halt, the negative impact will predominate (path 8-10). Appendix 2 gives further details.

[Page 127]

Journal of World-Systems Research

\section{The Interventionist Sub-Model}

\section{State Intervention}

Each of the various development strategies pursued by the state is a package of policies. The strategy of import substitution industrialization (ISI), for instance, is made up of a policy package which contrasts with that for the export substitution industrialization (ESI) strategy. The state's choice of policies changes over time, in response to past failures, to new challenges from the world-system (e.g. external shocks), and to the political orientation of a new regime. Seven policy dimensions have been selected to represent state intervention in accordance with the various development strategies. The policy dimensions include the regulation of foreign direct investment, the promotion of agriculture, subsidies to industry, the exchange rate, state enterprises, unionization of labor, and wages. Each state policy is defined below and linked to a group of variables in the dependency sub-model. Using the same set of policy dimensions for both Korea and Argentina enables us to compare their changing strategies over time.

[Page 128]

Journal of World-Systems Research 
Foreign investment and tariff policy. This policy dimension varies from (high) the promotion of branch plants of multinational corporations to (low) the promotion of export platforms of MNCs. The policy instruments are two: the level of tariffs and the foreign investment code. High protective tariffs and an investment code with incentives (e.g. tax holidays, high limits for profit repatriation) for branch plants indicate "high" on this policy dimension. Low tariffs and an investment code with incentives for export platforms indicate "low" on this dimension.

POLICY 1. The higher the tariffs and incentives for branch plants, the more branch plants predominate over export platforms among new subsidiaries.

Agriculture policy. This policy dimension varies from (high) support to (low) neglect of agricultural production. The chief policy instruments are farm credit subsidies, rural infrastructure investment, and the internal terms of trade between agriculture and industry. Making credit available, building infrastructure, and supporting terms of trade favorable to agriculture indicate "high" on this policy dimension. "Low" signals the opposite policy conditions.

[Page 129]

Journal of World-Systems Research

POLICY 2. The more internal terms of trade favor agriculture, the less the dependence. Dependence here pertains to agricultural production that either fails to meet the requirements of food self-sufficiency or limits the agricultural surplus available for export.

Banking policy. Loans may be subsidized through reduced interest rates and made available to selected categories of industrial firms. "High" indicates preferential credits to larger, capital-intensive, industrial firms while "low" indicates preferential credit allocation to smaller, labor-intensive firms.

POLICY 3. The more the subsidization of capital-intensive firms, the greater the capital intensity and industrial concentration.

Exchange rate policy. Through devaluation the state can bring about undervaluation of the national currency. The high ratio of the local currency to the dollar gives a "high" exchange rate. Overvaluation comes from a revaluation of the local currency, or "low" ratio of local currency to the dollar.

POLICY 4. The more the undervaluation of the exhange rate, the greater the reserves of foreign exchange. 
Public investment policy. The creation and expansion of state firms may accompany state investment in infrastructure, signifying "high" promotion. When investment in infrastructure declines and state enterprises are privatized, promotion is "low".

[Page 130]

Journal of World-Systems Research

POLICY 5-Growth. The less the expansion of state enterprises (more privatisation), the greater the rate of economic growth

(see Appendix 2 for several contingencies).

Wage policy. "High" signifies that the state sets high wages in the public sector and allows private sector wages to rise as well. "Low" means that public and private sector wages are frozen or rolled back and that penalties may be imposed on firms that fail to conform.

POLICY 5-Equality. The higher the wage setting, the greater the equality (see Appendix 2 for several contingencies).

Labor policy. "High" refers to permissive and pro-labor union legislation. "Low" means the opposite, anti-labor laws affecting union rights and conflict settlement procedures.

POLICY 5-Liberty. The more pro-labor the union legislation, the greater the liberty.

[Page 131]

Journal of World-Systems Research

\section{Effectiveness of State Intervention}

The state's choice of policies, as indicated in the interventionist sub-model, influences developmental performance. According to a number of researchers on divergent development, the "effectiveness of state intervention" further influences policy impacts on development (Jenkins; Rueschemeyer and Evans; Anglade and Fortin). State effectiveness refers to the rationality of policy choice and the fullness of policy implementation. Effectiveness encompasses 1. flexibility: the ability to change policies in response to unsatisfactory impacts, 2 . selectivity: the use of policies that target specific groups of firms, 3. coherence: consistent and coordinated policies, and 4. promotion: policies that give incentives rather than regulations to private enterprises (Jenkins: 199200). 
Of the many conditions which contribute to state effectiveness (e.g. the type of regime, the class alliance with the state, and state bureaucratic capacity) researchers generally posit the relative autonomy of the state from dominant classes. "High" effectiveness then derives from the high relative state autonomy from dominant classes, allowing the state to govern in the long term interests of society as a whole. "Low" effectiveness stems from low relative state autonomy, when the state is bound to act more as the instrument of the dominant classes (Jenkins: 200, 202). These complex ideas may be simplified in one causal proposition: the greater the relative autonomy of the state from the dominant classes, the greater the effectiveness of state intervention.

[Page 132]

Journal of World-Systems Research

The location of this proposition in the model is described in the Appendix 2. State effectiveness influences the impact of policy five on growth and equality.

\section{External Shocks}

In two ways so far our model incorporates linkages between the national political economy and the world-system: through the presence of multinational corporations and the relations of dependence. The international conjuncture changed radically at three particular moments during the period under study. These moments are the external shocks of 1973, 1979, and 1982 (Masini). The influence of these shocks on the development of the NICs is mediated by the variables in the dependency sub-model and provokes state responses in the interventionist sub-model (Ominami). Taking the policy context into consideration enables our model to reflect the different impacts of the external shocks on development in Korea and Argentina.

1973: The first oil shock created an abundance of liquidity through the recycling of petrodollars for the LDCs. This, in addition to the low real interest rate for international borrowing, reduced debt dependence. The devaluation of the dollar, due to the termination of the gold standard, stimulated an increase in the international prices for raw material exports from LDCs, leading to an increase in their foreign exchange reserves.

[Page 133]

Journal of World-Systems Research

1979: The second oil shock and the rise in U.S. interest rates increased debt dependence in LDCs. The revaluation of the dollar contributed to a fall in the prices for raw material exports from LDCs, leading to a decline in their foreign exchange reserves. 
1982: The return of recession in DCs reduced their demand for LDC exports. The lack of liquidity (new loans) for LDCs and the increase in the debt service combined to reduce their foreign exchange reserves.

According to these descriptions, the external shocks influence the dependency sub-model at two points of vulnerability: debt dependence and foreign exchange reserves. Since propositions $8,9,10$, and 11 link these two points with development, our model incorporates the external shocks into our explanation. Our model contextualizes the impacts of external shocks by placing them in the conjuncture of all the other causal relations operating at the time of the shocks (see Appendix 2).

[Page 134]

Journal of World-Systems Research

\section{THE METHODS}

The general methodological approach of this study, comparative historical analysis, encompasses a number of specific methods: the "comparable-cases strategy" to guide the selection of cases, "qualitative causal path analysis" to formulate testable predictions, and

"analytic induction" to guide the dialog between theory and data.

\section{The Selection of Cases}

\section{The Comparable-Cases Strategy}

At first glance it may not seem feasible to compare the development of two countries, Korea and Argentina, on the basis of five or more variables simultaneously. We appear to be facing the dilemma of "too few cases and too many variab les", noted by Lijphart (57). By placing the many variables into only five groups we have already followed his advice in one respect. Lijphart also recommends increasing the number of cases by extending the study longitudinally so as to study the same nation at more than one point in time (Lijphart: 56,61). We have done this by identifying as our "cases" the key time periods within the history of Argentina and Korea. Any year in which policies change or external shocks occur marks the beginning of a key pe riod as temporal case. Our study spans thirty years, from the early 1960 s to the early 1990s, which we have divided into six key periods for Korea and seven for Argentina.

[Page 135]

Journal of World-Systems Research

Lijphart describes the logic of hypothesis testing when the cases are selected in order to maximize their similarity on the control variables, as we have done. By comparing the 
key periods of a nation the cases are maximally similar on such control variables as colonial history, culture, geography, and geopolitics. The variation of control variables, external to our theoretical model, is minimized while the variation in the independent variables (the policy variables and external shocks) and dependent variables (the development variables) is maximized. It then becomes possible to assess the covariation of the independent and dependent variables, while non-relevant conditions are "held constant". This is the logic of hypothesis testing within the "comparable-cases strategy", also known as the "most similar systems" design (Lijphart: 59).

\section{The Formulation of Testable Predictions}

\section{Causal Complexity}

Comparative case studies or "case-oriented comparative methods" have several advantages over "variable-oriented methods" (Ragin, 1987: 15-16). Our model and its testing incorporate especially one of these advantages, "causal complexity". Explanations of development generally include multiple causes which act in combination. The eleven causal linkages in our model, plus the external shocks, combine in a comp lex way to influence developmental performance. By following Ragin's distinction between "multiple and conjunctural causation" we can observe how our model incorporates this causal complexity. Conjunctural causation refers to the "intersection of a set of conditions in time and space" that produces changes, "...not the separate or independent effects of these conditions" (Ragin, 1987: 25). The eleven causal relations in our model describe "the intersection of a set of conditions" (the high or low values of the policies and external shocks) in time (during a key period) and space (in a country). A further aspect of conjunctural causation is the "context". A particular causal condition "may have opposite effects depending on the context" (Ragin, 1987: 27,48). In our model, causal link 11 relates "capital intensity" to "growth" in two opposite ways, depending on the context, East Asia or Latin America. In the Latin American context capital intensity promotes growth, while in East Asia labor intensity promotes growth. The context here is the overall development strategy founded on comparative advantage in abundant unskilled or skilled labor.

[Page 136]

Journal of World-Systems Research

Multiple causation refers to the situation where several different combinations of conditions produce the same effect (Ragin, 1987: 25). In our model the same effect, an increase in liberty, equality or growth may occur with different combinations of policies. Here are two different policy combinations both of which may promote economic growth: low tariffs-neglect of agriculture-high industrial subsidies-currency overvaluation and high tariffs-agricultural promotion-high industrial subsidies-currency undervaluation. The formulation of our predictions for the key periods allow for multiple causation in just this way. 


\section{Qualitative Causal Path Analysis}

In order to test the causal model we formulate a series of predictions which are then compared to empirical observations. The observations are the tendencies of change in growth, equality, and liberty in each of the key periods, our cases. The predicted tendencies for each key period derive from a method called "qualitative causal path analysis" (QCPA). Our method is analogous to quantitative causal path analysis which applies to interval level data. Since our model incorporates ordinal dichotomous data (high versus low, present versus absent) on policies, external shocks, and state effectiveness, an alternative method is required. Much of the logic of QCPA is borrowed from its quantitative analog: 1. the correlation between two variables can be decomposed into the sum of simple and compound paths; 2 . a compound path is the product of the simple paths comprising it (Asher: 32-33). The application of QCPA to formulate predictions from our causal model is described in Appendix 1.

[Page 137]

Journal of World-Systems Research

\section{The Dialogue between Theory and Data}

\section{Analvtic Induction}

Our research process is neither wholly inductive nor deductive, but lies somewhere between as an instance of analytic induction (Rueschemeyer, 1991; Ragin, 1994). We begin with a thoroughly reflected analytic framework of concepts and relationships taken largely from Alschuler (1988), Ominami (1986), and Gereffi and Wyman (1990). In a second step we formulate a number of predictions about developmental tendencies (in growth, equality, and liberty) on the basis of the analytic framework. Next we adopt indicators for the three aspects of development and make empirical observations of these indicators in the key periods (cases) of Argentina and Korea. In a fourth step of analytic induction we compare predictions with observations in order to identify confirmed and unconfirmed cases. Our dialogue with the data enters a final stage when we treat the unconfirmed cases as anomalies and make revisions in the model or in the techniques of observation in order to reduce the number of anomalies.

[Page 138]

Journal of World-Systems Research

\section{The Calculation of Empirical Tendencies}

\section{Comparative averages}


The predicted tendencies in each key period are compared with the observed tendencies in growth, equality, and liberty. The annual data on each aspect of development are averaged for each key period. The average of each key period is compared with the average of the preceding period, resulting in three possible empirical tendencies: "increase", if the previous period average is lower; "decrease", if the previous period average is higher; "stability", if the previous period average is the same.

In order to complete the task of formulating predictions we need to assign empirical values of "high" or "low" to each of the five policies, to effectiveness of state intervention, and to the three external shocks. Each of the key periods has a distinct set of initial values. Our study of the political economic history of Korea and Argentina covering the last three decades has enabled us to find these initial values. In the following section we describe the historical context of each key period in which the initial values are found. The section ends with a table of initial values for each country's key periods.

[Page 139]

Journal of World-Systems Research

\section{THE CASES}

\section{The Seven Argentine Cases}

For the most part, the key periods in Argentine history correspond to successive political regimes, beginning with the Frondizi regime in 1959. Whenever successive regimes followed essentially the same set of policies, these have been fused into a single key period in our analysis. The initial period (1959-62) marks the start of the second phase of the strategy of import substitution (ISI-2), following the Peronist period of ISI-1 and military interlude. As in the study of Korea, we begin at the historical moment when the development strategies of the two countries diverge from their common base, ISI-1. The description of each period emphasizes the class alliance with the state, the challenges, and the development strategy.

\section{9-1962: Frondizi (Government of the Intransigent Radical Civic Union Party)}

The social class coalition supporting Frondizi's civilian government consisted of the large industrial bourgeoisie, the agrarian bourgeoisie, excluding mainly organized labor and the entrepreneurs of small and medium firms (Peralta-Ramos: 36). The development strategy promoted larger, capital-intensive industrial firms through tariff protection, credit subsidies, and the encouragement of foreign direct investment. Currency devaluation encouraged agricultural exports, contributing to foreign exchange reserves and to state revenues through export taxes. Though an IMF stabilization plan enabled Argentina to move out of a recession, the social costs were high in terms of falling real wages, bankruptcies of smaller firms, and new forms of dependence on foreign capital (Alschuler: 41-43). 
[Page 140]

Joumal of World-Systems Research

\section{3-1965: Illia (Government of the Radical Civic Union of the People Party)}

The intended class allies of the Illia government were industrial labor and the smaller industrial firms, to the exclusion of the agrarian and large industrial bourgeoisies. Facing mounting external debt and recession, the strategy promoted agro-exports (to help pay the debt) and raised wages (to enlarge the domestic market for industrial production). Taxes on agro-exports were channelled through credit institutions to industrial firms (Alschuler: 44-45). Economic growth was restored and the foreign debt reduced, though at the cost of depending on unreliable agro-exports and ever more on foreign capital which dominated the most dynamic and concentrated branches of industry. Heavy industry imported large volumes of intermediate goods but exported little, contributing to a foreign exchange bottleneck (Alschuler: 45-46).

\section{6-1972: Ongania, Lanusse (military government called "The Argentine Revolution")}

The military coup d'état, to preclude the political reassertion of the Peronist movement, brought to power a coalition of the large industial bourgeoisie and foreign capital, excluding the agrarian bourgeoisie, the smaller industrial bourgeoisie, and labor. This type of regime has been labelled "bureaucratic authoritarian" (O'Donnell) and a "triple alliance" between the state, multinationals, and local capital (Evans, 1979). The strategy emphasized heavy industrialization, to be led by public investment (Canitrot, 1978: 9). High protective tariffs as well as tax and financial subsidies combined to promote higher efficiency and concentration among the heavy industries (Peralta-Ramos: 50). Wage controls transferred income from labor to capital. The combination of price controls on agricultural products and export taxes transferred income from rural to urban capitalists (Canitrot, 1978: 9). Economic growth was achieved at the cost of political liberty and income equality, leading to a legitimacy crisis and the military's willingness to return to civilian rule.

[Page 141]

Journal of World-Systems Research

\section{3-1975: Peron (the government of the Justicialista Party)}

After eighteen years in exile Peron returned to govern a nation divided by class antagonisms and his own Party divided into socialist and moderate wings. Peron forged a coalition within the moderate wing which took the form of a social pact between the peak associations of organized labor and entrepreneurs of the medium size firms, reminiscent 
of the Peronist alliance of the 1950s (Peralta-Ramos: 63). Faced with slow economic growth, inflation, a fiscal deficit, and lagging real wages (Canitrot, 1978: 12-13), the strategy had to reconcile capital accumulation and income distribution. Wages and prices were monitored and increased by negotiation. A new export tax on agriculture and a reduction in meat and wheat prices created unfavorable terms of trade for agriculture and a shift of income to industry (Peralta-Ramos: 63). Subsidies to the more capital-intensive firms for imported inputs helped to offset the rising cost of imports following the oil shock in 1973. After Peron's death in 1974, the succession of Isabel Peron to the Presidency ushered in a period of "state terrorism" as economic conditions worsened and as the two wings of the Peronist movement engaged in armed confrontation (PeraltaRamos: 64-65).

[Page 142]

Journal of World-Systems Research

\section{6-1982: Videla, Viola, Galtieri (government under alternating branches of the military)}

The military applied stabilization policies to provide temporary relief from hyperinflation and the huge public sector deficit. In their view only economic liberalism could remedy the long term problems that started with Peronism in 1946 (Canitrot, 1980: 914-915). The reversal of import substitution policies was thorough. Wages were lowered so as to correspond to productivity levels. Export taxes on agriculture were eliminated. Tariffs were lowered progressively, subjecting manufacturing firms to the discipline of foreign competition (Peralta-Ramos: 77). Subsidies were all but eliminated, save for a nucleus of strategic firms producing intermediate goods and with access to foreign credit.

Government expenditure was reduced and public enterprises were privatized (Canitrot, 1980: 917; Peralta-Ramos: 73-74).

The second oil shock of 1979 and the increase in interest rates on the debt forced the military government to increase its foreign borrowing in order to meet the growing demand for scarce foreign reserves (Canitrot, 1994: 79). In 1982 the private foreign debt was nationalized. The failure of devaluation to bring a trade surplus for servicing the foreign debt led to the suspension of debt service payments in 1982. Following the Mexican debt crisis foreign credit was cut off.

[Page 143]

Journal of World-Systems Research

The period ended in "complete economic disorder": high inflation, high fiscal deficit, and falling real wages (Canitrot, 1994: 76). Unprecedented "state terrorism" was aimed chiefly at the Peronists and their union leaders in the "dirty war" (Peralta-Ramos: 70). 
After the disastrous military defeat in the Falklands War with Britain in 1982, the government lost legitimacy both as guarantors of welfare and sovereignty.

\section{3-1988: Alfonsin (Government of the Radical Civic Union Party)}

Facing the Radical Party, elected over the opposition of the Peronist Party, was the need to restore legitimacy to the constititional system in the wake of the period of state terrorism. The state also confronted the persistent problems of income distribution, runaway inflation, and the foreign debt (Peralta-Ramos: 87). Following the failure of policies like those of the 1960s, in 1985 Alfonsin engaged in economic liberalization, called the Austral Plan, resembling that of the previous military government (PeraltaRamos: 95, 102). The Plan promoted both agricultural and industrial exports in order to continue the service payments on the external debt. To make industry more efficient and profitable, tariff protection was reduced along with a reduction in real wages (PeraltaRamos: 95). Public utility rates were raised so that state enterprises could cover their costs and pay their foreign debt. Certain state enterprises were privatized in order to increase their productive efficiency (Peralta-Ramos: 103).

[Page 144]

Journal of World-Systems Research

The priority given to debt servicing reduced the resources for industrial subsidies, sharpening the struggle over income redistribution and slowing economic growth (Peralta-Ramos: 109). The losers in this struggle were the wage earners and a new class of "paupers" in the major cities (Smith: 30). The Peronist victory in the 1989 elections was the popular response to these failed policies.

\section{9-1991: Menem (Government of the Peronist Party)}

The Peronist government under Menem took office in the midst of economic chaos: hyperinflation, food riots, a recession, and a fiscal deficit out of control (Peralta-Ramos: 142, 147; Smith: 28-29). The new cabinet was dominated by non-Peronists from the "liberal" right wing of the business community, the legendary opponents of Peronism (Peralta-Ramos: 147). Menem's neo-liberal "productive revolution" moved away from the traditional Peronist aims of income distribution within a protected domestic market. The general objectives were to insert Argentina competitively into international markets and to attract foreign capital (Ranis: 614,618). The policies of "economic liberalism" included an overvaluation of the currency, tariff reduction, wage increases, and privatization of state enterprises (Canitrot, 1994: 89-90). New regulations put foreign capital on an equal footing with Argentine private firms (Ranis: 615-16).

[Page 145]

Joumal of World-Systems Research 
As of 1992 the results were largely positive: a reduction in inflation and the fiscal deficit accompanied by an improvement in the balance of trade, economic growth, and employment (Canitrot, 1994: 89; Ranis: 616-617, 625). The absence of general strikes through mid-1991 may be understood as unionized labor's approval of the new labor policies.

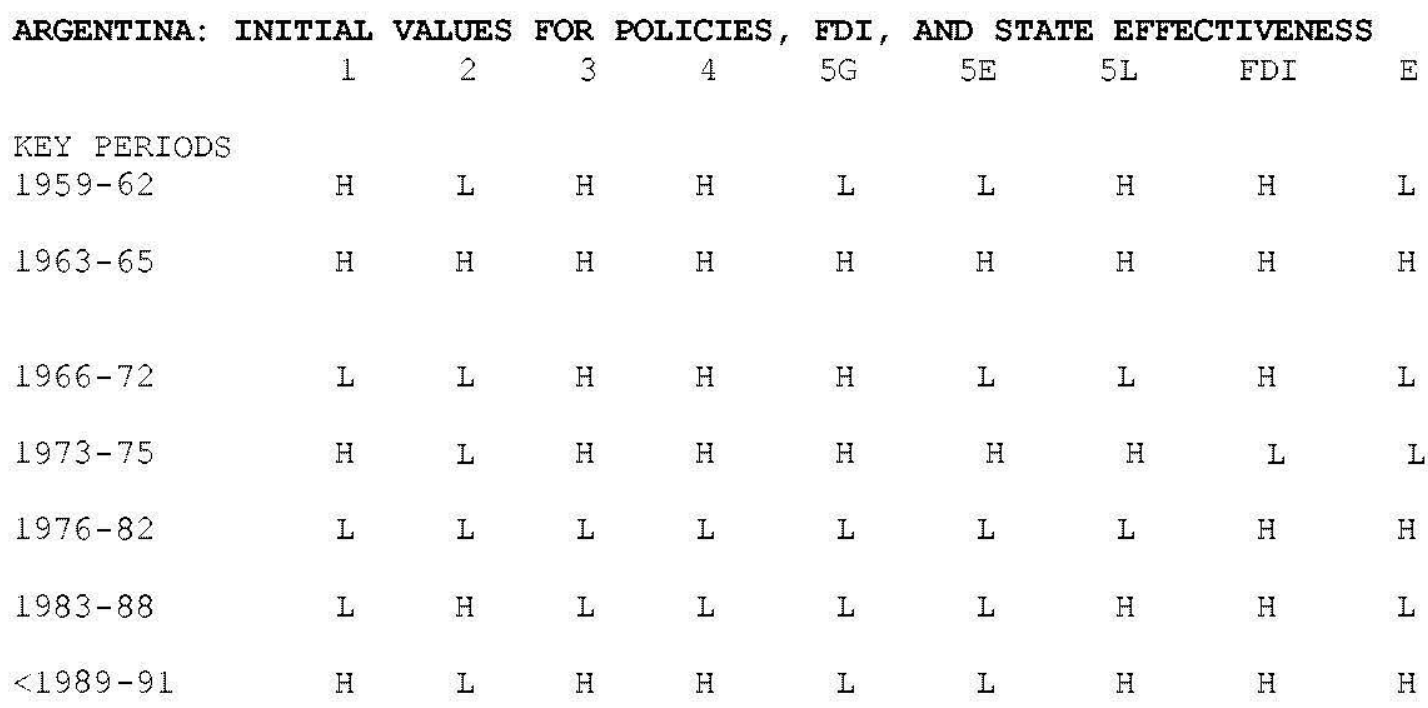

1. FOREIGN INVESTMENT AND TARIFF POLICY

$\mathrm{H}=$ high tariffs and investment code promoting branch plants for the domestic market

$L=10 \mathrm{w}$ tariffs and investment code promoting export platforms

2. AGRICULTURE POLICY

$\mathrm{H}=$ terms of trade in fav or of agriculture, high infrastructure

investments, farm credits, high farm support prices

$L=$ terms of trade disfavoring agriculture, low infrastructure investments, low farm credits, low farm support prices

3. BANKING POLICY

$H=$ selective credit allocation in favor of large, capital intensive firms

$\mathrm{L}=$ selective credit allocation in favor of small and medium, labor-intensive firms, sometimes on the basis of export performance

4. EXCHANGE RATE POLICY

$\mathrm{H}=$ under-valuation through devaluation: high exchange rate, high local currency to the dollar

$\mathrm{L}=$ over-valuation

5G. PUBLIC INVESTMENT POLICY (FOR GROWTH)

$\mathrm{H}=\mathrm{high}$ amount of state investment in public enterprises 


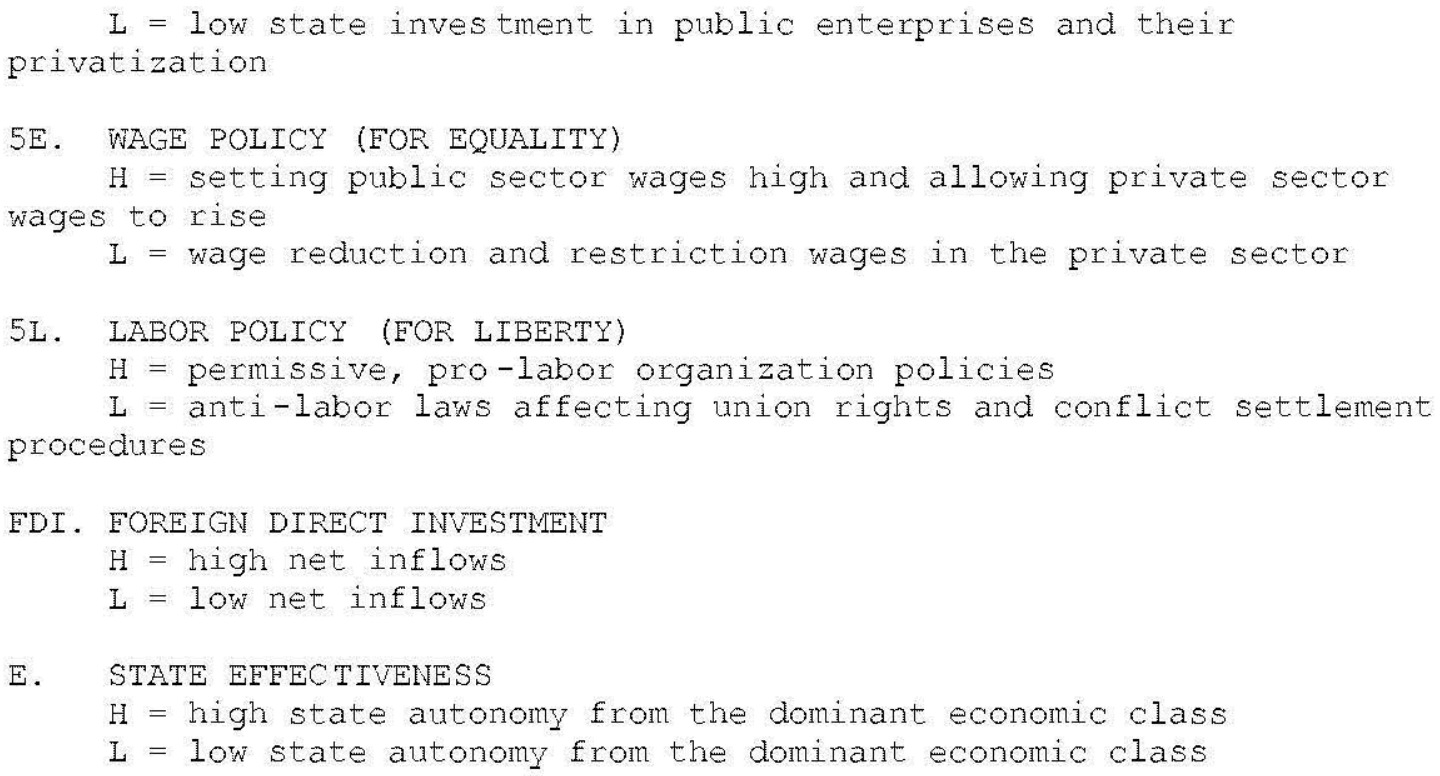

[Page 146]

Journal of World-Systems Research

\section{The Six Korean Cases}

The identification of key periods for Korea is guided by the major policy shifts and external shocks which will influence the development tendencies, according to our model. In many studies of Korea researchers customarily identify as key periods the fiveyear development plan periods, beginning with 1961-1966 and ending with 1987-91. We have not followed this procedure for the simple reason that shifts in policies do not necessarily coincide in time with the announcement of policy objectives in the five-year plans. The case descriptions focus on challenges and policy shifts.

\section{1-1964: Park (military government called "guided capitalism")}

The legitimacy of the dictatorship, brought about by Park's military coup in 1961, would depend on the restoration of economic growth and self-reliance. During the early years of "guided capitalism", as expressed in the first five-year plan, the goals were heavy industrialization for the domestic market, increased primary exports, and agricultural selfsufficiency (Hart-Landsberg: 140). Already by 1964 a number of pressures forced a reorientation of the development strategy from import substitution to export substitution. Faced with declining U.S. foreign aid and foreign exchange reserves, the military government imposed an export-oriented manufacturing strategy as a promising alternative, despite objections by the industrial elite (Hart-Landsberg: 140-3).

[Page 147]

Joumal of World-Systems Research 


\section{5-1972: Park (military government called "unbalanced growth")}

Under the conditions of the Normalization Treaty with Japan, signed in 1965, Japanese loan capital more than compensated the reduction of U.S. aid (Hart-Landsberg: 145). As Japanese investors took advantage of low wage Korean labor, especially in the newly established export-processing free trade zones after 1970, the U.S. market absorbed the majority of these new exports (Hart-Landsberg: 150, 158).

Within the export substitution strategy the main policy instruments were an undervalued exchange rate to promote the competitiveness of exports, tax exemptions for exporters, tariff exemptions for imported inputs used in exports, subsidized interest rates for exporters, the construction of export processing zones, and control over agricultural prices (Hart-Landsberg: 170-71). Government control over grain prices and farm credit had two consequences for export-led growth. Lower grain prices provided cheap wage goods for urban labor, enabling entrepreneurs to keep labor costs down. Lower prices and insufficient farm credit drove impoverished farmers to the cities in search of work in industry (Hart-Landsberg: 171-74).

[Page 148]

Journal of World-Systems Research

\section{3-1978: Park (military government called "the Yushin period")}

The previous period of unbalanced growth generated pressures for a revised strategy. Political pressures from the countryside derived from the growing income gap between urban and rural populations. Economic pressures derived from the balance of payments difficulties due to the heavy reliance on imported inputs for the export industries (HartLandsberg: 189-90). Competitive pressures in export markets derived from increasing protectionism, declining demand for Korea's light manufactured exports during the recession in advanced countries, and the rising competition from lower-wage exporters.

In response to these pressures and conditions the development strategy shifted dramatically. A shift toward the revitalization of agriculture took place through credit, higher guaranteed grain prices, and rural-based industries for off-season employment in the early 1970 s.

In industry emphasis shifted to the creation of highly skilled labor for new capitalintensive, heavy and chemical industries (HCI). The HCI firms supplied the light manufacturing export firms with locally produced inputs, especially of chemicals, petrochemicals, iron and steel, and electronics, all in order to maintain Korea's competitive advantage. Control of the banking system enabled the state to create "policy loans" for 
targeted industries in the HCI sector, especially the chaebols (large Korean

conglomerates).

[Page 149]

Journal of World-Systems Research

Labor absorbtion reached a turning point in 1975 , resulting in pressures for wage increases. The state responded by the restriction of labor union rights and by police repression (Hart-Landsberg: 183, 197-8). Wage pressures induced the new HCI firms to become more capital-intensive and reliant on higher technology.

Multinationals and chaebols benefited from tariff protection, the former providing investment capital and new technology without adding to the debt service.

\section{9-1981: Chun (military government)}

The second oil shock and the renewed recession in advanced countries provoked a recession and political turmoil in Korea (Hart-Landsberg: 192). The HCI drive of the previous period promoted the chaebol firms through policy loans resulting in increased government foreign borrowing and in over-investment in under-utilized industrial capacity (Hart-Landsberg: 193). Reliance on multinationals to provide modern technology also worsened technological de pendence and balance of payments problems (Hart-Landsberg: 194). Korea's massive construction projects in the Middle East had the effect of pushing up manufacturing wages at home. As wage increases outpaced productivity increases, light industry faced a squeeze on profits (Hart-Landsberg: 195) and a loss of competitiveness in export markets.

[Page 150]

Journal of World-Systems Research

Park's responses to these problems triggered a recession and massive protests by labor, farmers, students, and church organizations (Hart-Landsberg: 195, 212). Park declared martial law and then planned a "major military offensive". To avoid a bloodbath, the head of the KCIA assassinated Park in October 1979. To foreclose any democratic opening, Major General Chun Doo Hwan took control in a military coup at year's end (HartLandsberg: 213-214).

Consolidating state power under martial law, Chun set the stage for new economic policies by repressing the political opposition, by taking over the mass media, and by controlling the labor unions (Hart-Landsberg: 219). This repression forced wages down while allowing productivity to rise, "a central part of Chun's strategy for restoring South 
Korea's economic competitiveness as well as its attractiveness to multinational capital" (Hart-Landsberg: 221).

\section{3-86: Chun (military government)}

The catchword of this period was "liberalization": market, import, and financial. Some of the import restrictions that had been in place during the 1973-78 HCI drive to protect infant industries were reduced. Complementing this was a selective privatization of many state firms, retaining those in strategic positions to influence the market and provide critical links between branches. More significant yet was the liberalization of the financial system: privatization and deregulation of national banks (Hart-Landsberg: 233). Chun's intentions were to "weaken chaebol power and to force them to become more efficient producers", by forcing them to sell off their non-productive investments to meet credit obligations and to reinvest according to state priorities (Hart-Landsberg: 234).

[Page 151]

Journal of World-Systems Research

Contrary to Chun's intentions, the chaebol took control of many financial institutions and grew by merging and buying out other firms (Hart-Landsberg: 234-5). Policy loans were reduced in importance while small and medium export firms in light manufacturing regained access to credit on terms equal to the chaebol, that is based on their record of export performance.

\section{7-1991: Roh (civilian government)}

The rapid growth of the economy in the previous period has been attributed to the "three lows", low oil prices, low interest rates, and a low value of the won (Hart-Landsberg: 237), plus low wages. As these "lows" began to fade, sustained growth was at risk. The wave of strikes beginning in 1987 resulted in a rapid rise in wages, long held down by Chun's repressive labor policies (Hart-Landsberg: 238). Chaebol gains from the previous period's growth were being placed in speculative ventures such as real estate, rather than in improving Korea's international competitiveness (Hart-Landsberg: 238-239). The newly elected Roh government in 1988 faced the challenge of maintaining rapid growth.

[Page 152]

Journal of World-Systems Research

The strategy may be summarized as follows: "...the state still remains committed to an economy driven by chaebol production for export. Its short-term strategy for renewed growth has largely been directed toward forcing chaebol investment into productive core business activities; lowering the value of the South Korean won; reducing imports; and 
driving down wages" (Hart-Landsberg: 252). Control over wages has been exercised by imposing penalties on firms failing to adhere to guidelines and by police repression of strikers. Policy instruments included subsidized loans to chaebols and incentives for multinationals to provide new high technologies (Hart-Landsberg: 253).

KOREA: INITIAL VALUES FOR POLICIES, FDI, AND STATE EFFECTIVENESS

$\begin{array}{lllllllll}1 & 2 & 3 & 4 & 5 \mathrm{G} & 5 \mathrm{E} & 5 \mathrm{~L} & \mathrm{FDI} & \mathrm{E}\end{array}$

KEY PERIODS

$\begin{array}{cccccccccc}1961-64 & \text { L } & \text { H } & \text { L } & \text { H } & \text { H } & \text { L } & \text { L } & \text { L } & \text { H } \\ 1965-72 & \text { L } & \text { L } & \text { L } & \text { H } & \text { H } & \text { L } & \text { L } & \text { H } & \text { H } \\ 1973-78 & \text { H } & \text { H } & \text { H } & \text { L } & \text { H } & \text { L } & \text { L } & \text { H } & \text { H } \\ 1979-81 & \text { L } & \text { L } & \text { H } & \text { H } & \text { H } & \text { L } & \text { L } & \text { L } & \text { L } \\ 1982-86 & \text { L } & \text { L } & \text { L } & \text { H } & \text { L } & \text { L } & \text { L } & \text { H } & \text { L } \\ 1987-91 & \text { L } & \text { L } & \text { L } & \text { L } & \text { L } & \text { L } & \text { L } & \text { L } & \text { L }\end{array}$

1. FOREIGN INVESTMENT AND TARIFF POLICY

$\mathrm{H}=$ high tariffs and investment code promoting branch pla nts for the domestic market

$L=10 \mathrm{w}$ tariffs and investment code promoting export platforms

2. AGRICULTURE POLICY

$\mathrm{H}=$ terms of trade in favor of agriculture, high infrastructure investments, farm credits, high farm support p rices

$L=$ terms of trade disfavoring agriculture, low infrastructure investments, low farm credits, low farm support prices

3. BANKING POLICY

$\mathrm{H}=$ selective credit allocation in favor of large, capital-intensive firms

$L=$ selective credit allocation in favor of small and medium, labor-intensive firms, sometimes on the basis of export

performance

4. EXCHANGE RATE POLICY

$\mathrm{H}=$ under-valuation through devaluation: high exchange rate, high local currency to the dollar

$\mathrm{L}=$ over-valuation

5G. PUBLIC INVESTMENT POLICY (FOR GRONTH)

$\mathrm{H}=$ high amount of state investment in public enterprises

$\mathrm{L}=$ low state investment in public enterprises and their

privatization

5E. WAGE POLICY (FOR EQUALITY)

$\mathrm{H}=$ setting public sector wages high and allowing private sector wages to rise 


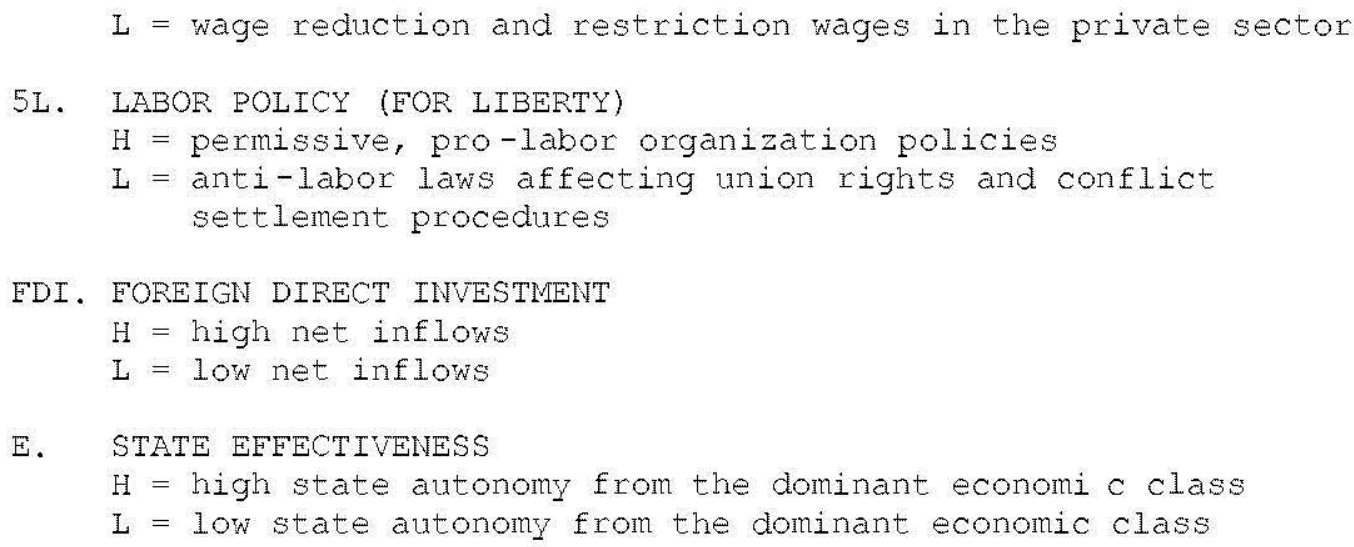

\section{THE RESULTS}

The seven Argentine cases and the six Korean cases are identified in the following tables by their span of years. Each case is located in the table according to its predicted tendency and observed tendency. The predicted tendency derives from three sources: 1 . the model: the thirteen causal links between the variables in the causal model; 2 . the initial values of each case (key period): for the five policies, for state effectiveness, and for the three external shocks; 3 . the method: qualitative causal path analysis whose logic combines the causes to generate predicted effects on development. The observed tendency derives from data which have been averaged for each key period (case) and compared with the average of the preceding period.

The tables should be read focusing on the principal diagonal which contains the confirmed (correctly predicted) cases. The cells in the principal diagonal are: increaseincrease, stability-stability, decrease-decrease. The off-diagonal cells contain the anomalies, the incorrectly predicted cases.

There are high rates of confirmation in the prediction of growth: five out of seven cases for Argentina and six out of six cases for Korea (Tables 1 and 2). The rates of confirmation in the prediction of equality are nearly as high: five out of seven cases for Argentina and four out of six cases for Korea (Tables 3 and 4). However the rates of confirmation in the prediction of liberty are disappointingly low: three out of seven for Argentina and only one out of six for Korea (Tables 5 and 6).

[Page 154]

Journal of World-Systems Research 
TABLE 1: GROWTH IN ARGENTINA

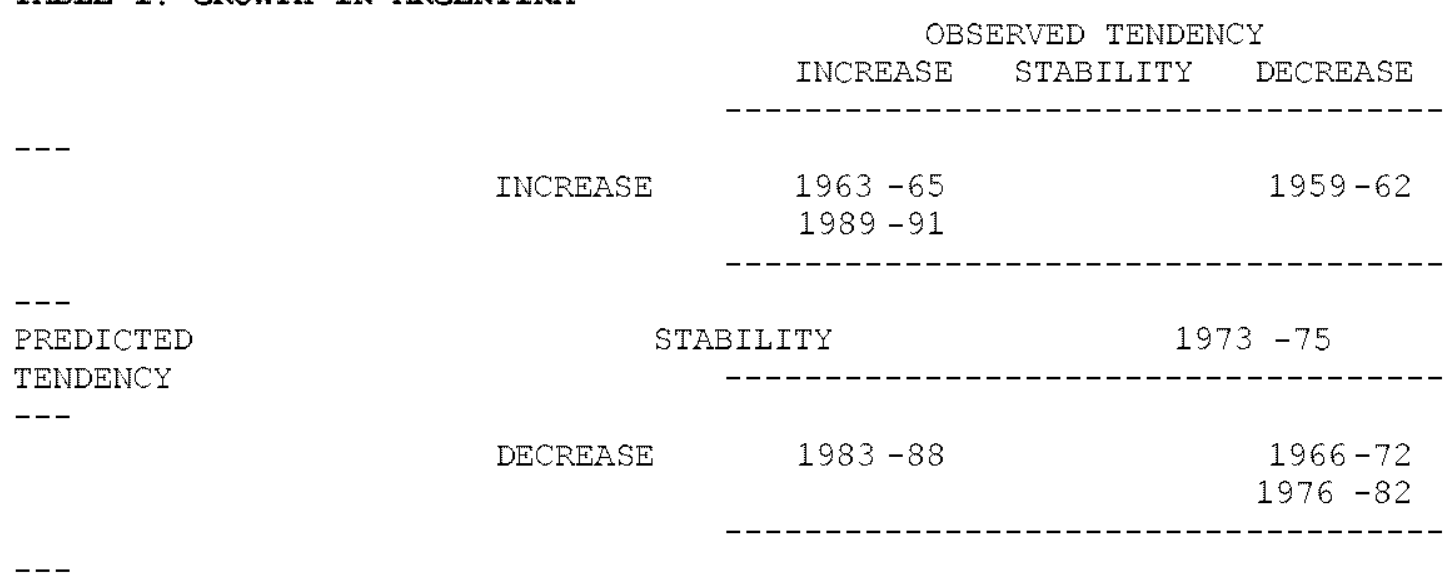

TABLE 2: GROWTH IN KOREA

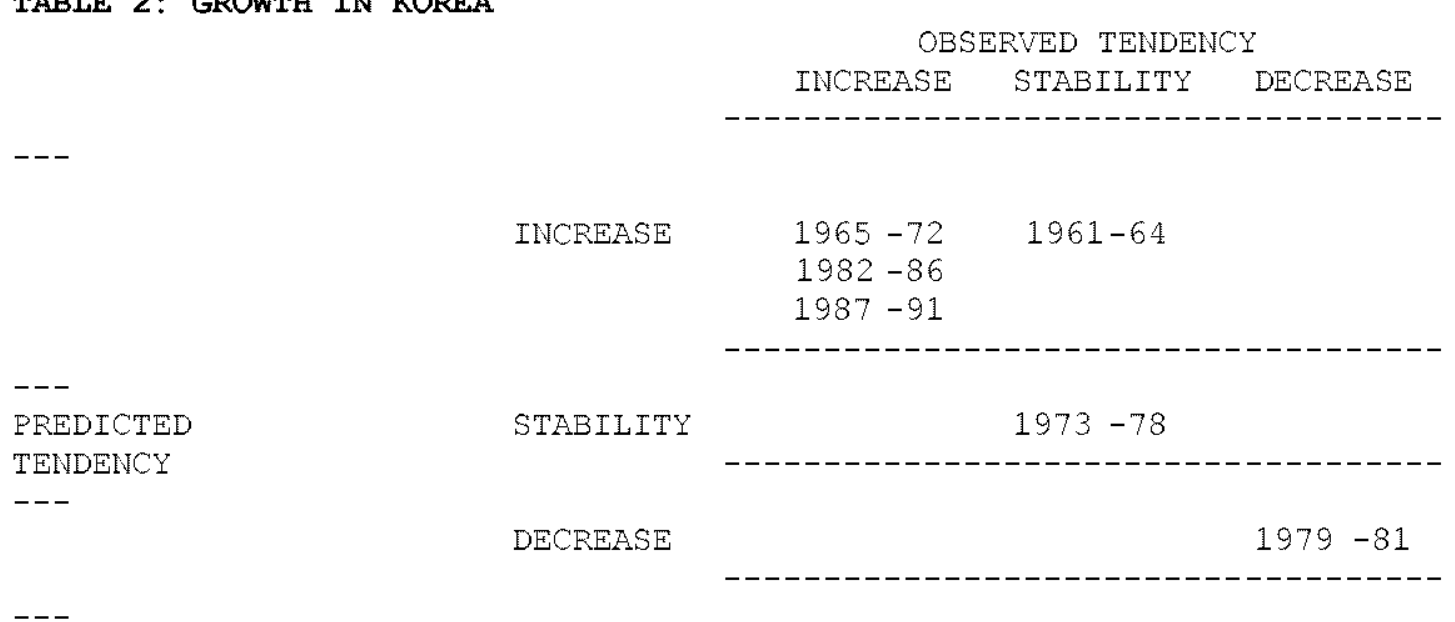

TABLE 3: EQUALITY IN ARGENTINA

\begin{tabular}{|c|c|c|c|c|}
\hline & & \multicolumn{3}{|c|}{ OBSERVED TENDENCY } \\
\hline & & INCREASE & STABILITY & DECREASE \\
\hline \multicolumn{5}{|l|}{---} \\
\hline & INCREASE & & $1963-65$ & \\
\hline \multicolumn{5}{|l|}{---} \\
\hline \multirow{3}{*}{$\begin{array}{l}\text { PREDICTED } \\
\text { TENDENCY } \\
---\end{array}$} & STABILITY & $1973-75$ & $1983-88$ & \\
\hline & & -------- & ---------- & --------- \\
\hline & DECREASE & & & 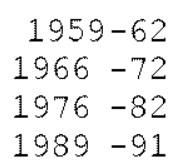 \\
\hline
\end{tabular}


TABLE 4: EQUALITY IN KOREA

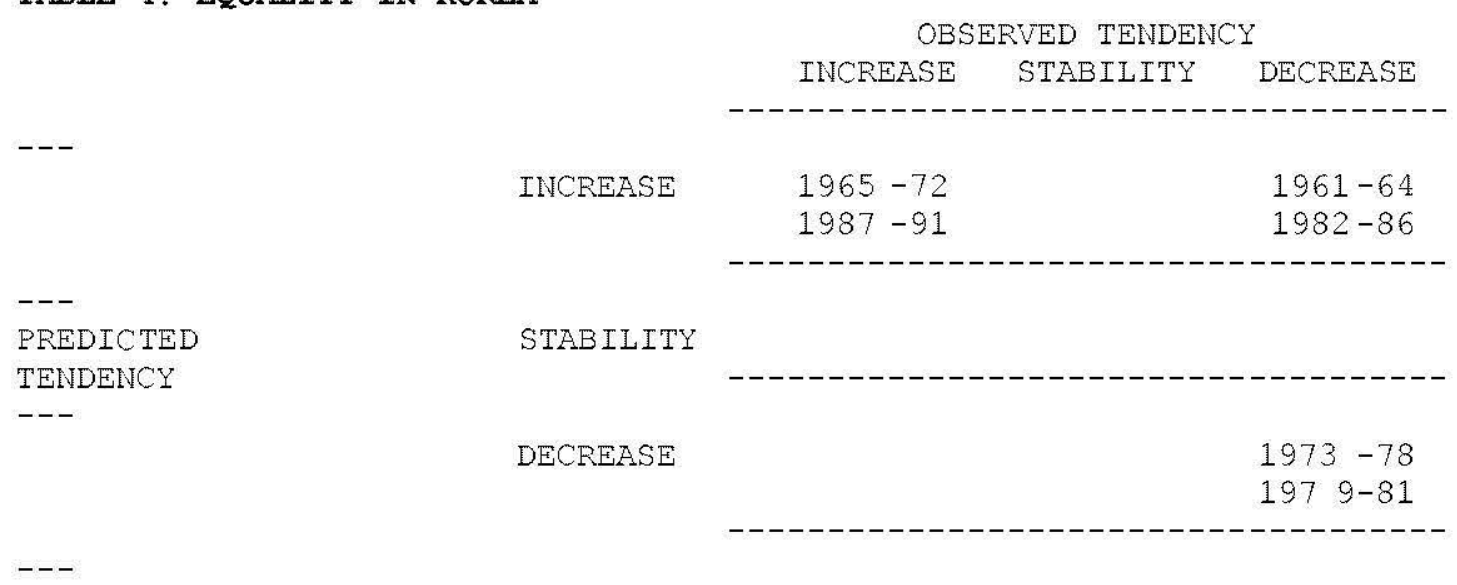

TABLE 5: LIBERTY IN ARGENTINA

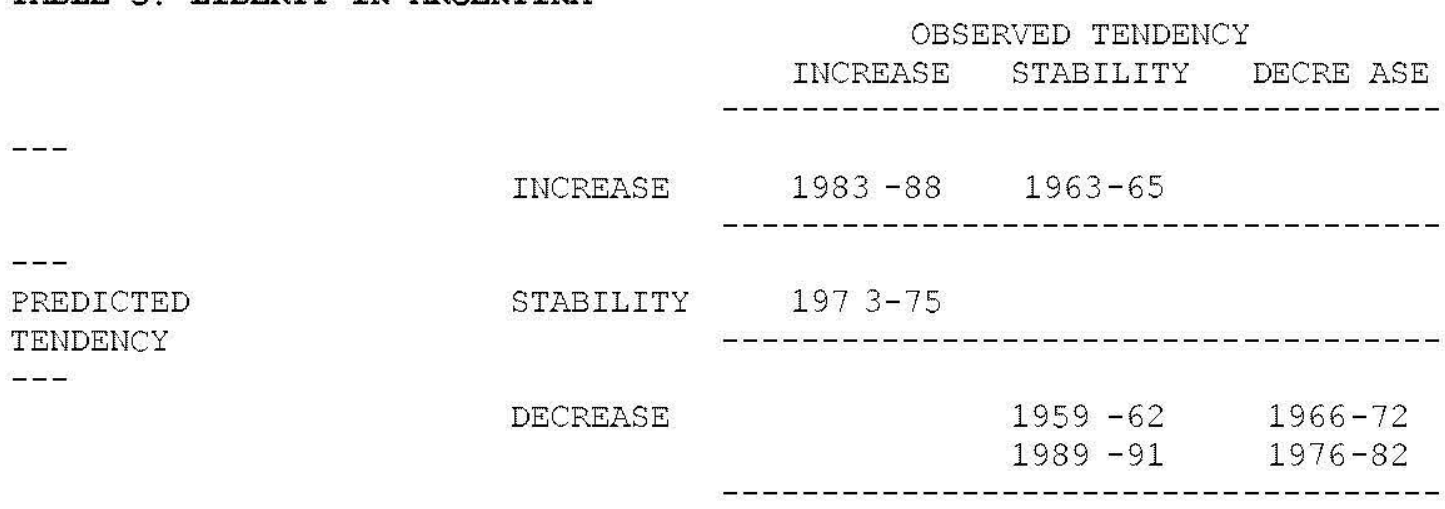

TABLE 6: IIBERTY IN KOREA

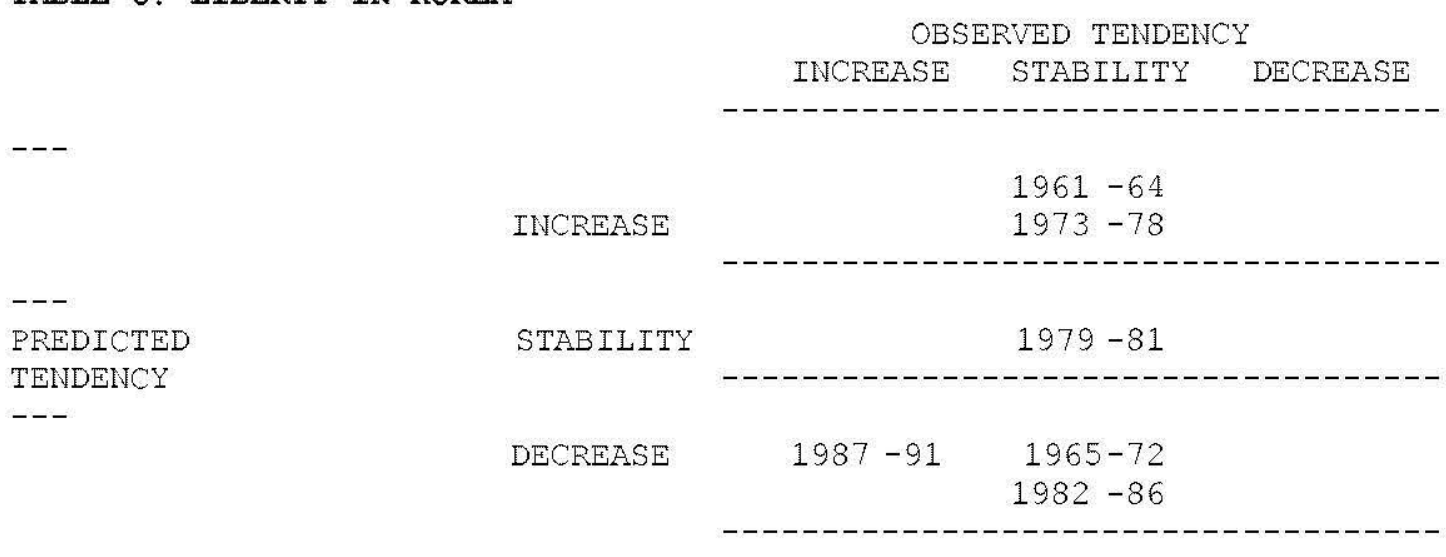

[Page 155]

Journal of World-Systems Research 
Anyone used to cross-tabulations is likely to ask whether our results are statistically significant. Our case-oriented analysis, however, is not a statistical technique. We are searching for patterns of invariance between causes (combined to produce predicted tendencies) and effects (observed tendencies) much in the tradition of J. S. Mill (Ragin, 1987: 39-40, 51-52). If our data were reliable and the indicators valid we would be required either to account for the anomalies or to reject the model. Our data, however, are not completely reliable for the indicators of growth, equality, and liberty. Gurr's data which we used for our indicator of liberty, for example, were collected and coded by one researcher and not subjected to any test of reliability (Gurr: 105-6). Our decision to average all years in a key period may not reflect the most appropriate time lags between causes and effects, casting some doubt on the validity of the indicators. Our coding of the five policies and state effectiveness (high and low) for each key period also is subject to error.

The formulation of predicted tendencies on the basis of the QCPA technique embodies a particular assumption, namely that all five policies are of equal importance. Perhaps some policies deserve more weight than others. In a similar way, the external shocks were weighted the same as a policy. Perhaps the weight of the shocks should be greater and should differ between Korea and Argentina.

[Page 156]

Journal of World-Systems Research

The causal model and the thirteen causal links making up the sub-models were formulated on the basis of past research findings and some untested theoretical expectations. If any sign ( + or - ) in a causal link is incorrect, the predicted period tendency might be affected.

As may be apparent from our summaries of the seven Argentine and six Korean cases, there are some unique events and conditions affecting the observed tendencies yet escaping our model. In Argentina, for example, the Cordoba uprising in 1969 and the death of Peron in 1974 had far-reaching impacts on development. In Korea the assassination of Park in 1979 and the Kwangju massacre in 1980 also influ enced developmental tendencies.

In our dialogue between theory and data that is called "analytic induction" we have already responded to the initial results (not reported here) by making some modifications that reduced the number of anomalies. For policy 1 we introduced the distinction between the influence of FDI stock and flow. Also, after trying several alternatives, we included the influence of state effectiveness on policy 5 for growth and equality. These modifications reduced the number of anomalies and so were incorporated into the model.

[Page 157]

Joumal of World-Systems Research 


\section{Conclusion}

It is fair to conclude on the basis of the above results and qualifications that our model accounts satisfactorily for growth and equality in the divergent de velopment of Argentina and Korea. The dynamics of liberty elude the predictive capacity of our model. In the light of these results we now turn to the questions and controversies mentioned at the outset.

With respect to the five points that structure recent research on divergent development our contribution may now be summarized.

1. The choice of development strategy has already been researched adequately and our study has not addressed this question.

2. Among the many conditions which influence the effectiveness of state intervention is state autonomy from the dominant class. Our results (rate of confirmation) were improved by including state effectiveness in our model. This provides needed empirical evidence for the relevance of effectiveness in the explan ation of divergent development.

3. The inclusion of several conditions of the world-system in our model has enhanced the rate of confirmation. In addition to the three external shocks, our model includes dependency relations and the presence of multination al corporations.

4. The importance of development strategies in the explanation of divergent development is an inescapable conclusion drawn from our results. The policy changes from one key period to another are correlated with changes in growth and equality.

5. Our model incorporates certain suppositions about compatible and incompatible aspects of development. The results confirm these suppositions, though with reservations concerning liberty. In Argentina growth tends to be incompatible with equality and liberty. In Korea liberty tends to be incompatible with growth and equality. At least some of the reasons may be gleaned from the summaries of the key periods (see "The Cases").

[Page 158]

Journal of World-Systems Research

Our results shed some light on the controversies over theory in the explanation of divergent development. Our model includes a dependency sub-model, representing many central propositions of neo-dependency approaches. The model also includes an interventionist sub-model, similarly representing many central propositions of neo-liberal approaches. Since our model combines both approaches and since the model is confirmed 
equally in an East Asian NIC and a Latin American NIC, we conclude that there is no need for a different theory for each region.

The controversies over the practice of development focus on the supposed superiority and replicability of the East Asian model. Over the last three decades Korea has caught up to Argentina's level of economic development. Korea's superiority in equality and liberty is less certain. Both countries have adjusted their policies continually from one key period to the next in response to changing domestic and international conditions. Over the last three decades the policies of these two countries have converged to a great extent (see the table of initial values in "The Cases"). In consequence we question the existence of a definitive East Asian or Latin American model to be exported. We prefer to believe that third world countries have much to learn from the experience of both these regions.

[Page 159]

Journal of World-Systems Research

\section{REFERENCES}

Alschuler, Lawrence (1988) Multinationals and Maldevelopment: Alternative Development Strategies in Argentina, the Ivory Coast, and Korea, London: Macmillan.

Amsden, Alice, ed. (1994) "The World Bank's East Asian Miracle: Economic Growth and Public Policy", World Development 22, 4 (April), pp. 615-670

Anglade, Christian and Carlos Fortin (1990) "The State, Relative Autonomy and Accumulation in Latin America: A Comparative Evaluation", in C. Anglade and C. Fortin, eds., The State and Capital Formation in Latin America, vol. 2, Pittsburgh: University of Pittsburgh, pp. 238-254.

Asher, Herbert B. (1976) Causal Modelling, Beverly Hills: Sage.

[Page 160]

Journal of World-Systems Research

Barrett, Richard and Martin K. Whyte (1982) "Dependency Theory and Taiwan: Analysis of a Deviant Case", American Journal of Sociology 87, 5 (March), pp. 1064-1089.

Biersteker, Thomas J. (1995) "The 'triumph' of liberal economic ideas in the developing world", in Barbara Stallings, ed., Global Change, Regional Response: The New International Context of Development, Cambridge: Cambridge University Press, pp. 174196. 
Bornschier, Volker and Christopher Chase-Dunn (1985) Transnational Corporations and Underdevelopment, New York: Praeger.

Broad, Robin and John Cavanagh (1988) "No More NICs", Foreign Policy, 72 (Fall), pp. 81-103.

Canitrot, Adolfo (1978) "La viabilidad economica de la democracia: un analisis de la experiencia peronista 1973-1976", Buenos Aires: Centro de Estudios de Estado y Sociedad.

[Page 161]

Journal of World-Systems Research

Canitrot, Adolfo (1980) "Discipline as the Central Objective of Economic Policy: An Essay on the Economic Programme of the Argentine Government Since 1976", World Development 8, 11 (November), pp. 913-928.

Canitrot, Adolfo (1994) "Crisis and Transformation of the Argentine State (178-1992), in William C. Smith, Carlos Acuna, and Eduardo Gamarra, eds. Democracy, Markets, and Structural Reform in Latin America: Argentina, Bolivia, Brazil, Chiile, and Mexico, New Brunswick, NJ: Transaction Publishers, pp. 75-95.

Cardoso, Fernando H. (1973) "Associated-dependent Development: Theoretical and Practical Implications", in Alfred Stepan, ed., Authoritarian Brazil, New Haven: Yale University Press, pp. 142-176.

Evans, Peter (1987) "Class, State, and Dependence in East Asia: Lessons for Latin Americanists", in Frederic Deyo, ed., The Political Economy of the New Asian Industrialism, Ithaca: Cornell University, pp. 203-226.

[Page 162]

Journal of World-Systems Research

Evans, Peter (1979) Dependent Development: The Alliance of Multinational, State, and Local Capital in Brazil, Princeton: Princeton University Press.

Fishlow, Albert et al. (1994) Miracle or Design? Lessons from the East Asian Experience, Washington, D.C.: Overseas Development Council.

Galtung, Johan et al. (1975) "Measuring World Development - II", Alternatives, 1, 2, pp. 523-555. 
Gastil, Raymond (1990) "The Comparative Study of Freedom: Experiences and

Suggestions", Studies in Comparative International Development, 25, 1, pp. 25-50.

Gereffi, Gary and Donald Wyman, eds. (1990) Manufacturing Miracles, Princeton, NJ:

Princeton University Press.

[Page 163]

Journal of World-Systems Research

Gurr, Ted, Keith Jaggers, and Will Moore (1990) "The Transformation of the Western State: The Growth of Democracy, Autocracy, and State Power Since 1800", Studies in Comparative International Development, 25, 1, pp. 78-85.

Haggard, Stephan (1990) Pathways from the Periphery: The Politics of Growth in the Newly Industrializing Countries, Ithaca: Cornell University.

Hart-Landsberg, Martin (1993) The Rush to Development: Economic Change and Political Struggle in South Korea, New York: Monthly Review Press.

Hasan, Parvez and D.C. Rao (1979) Korea: Policy Issues for Long-Term Development, Baltimore: Johns Hopkins University Press.

Hong, Wontack (1981) "Trade, Growth, and Income Distribution: The Experience of the Republic of Korea", Working Paper no. 3, Washington, D.C.: Overseas Development Council.

[Page 164]

Journal of World-Systems Research

Jenkins, Rhys (1991) "The Political Economy of Industrialization: A Comparison of Latin American and East Asian Newly Industrializing Countries," Development and Change 22, 197-231.

Koo, Hagen (1984) "The Political Economy of Income Distribution in South Korea: the Impact of the State's Industrialization Policies", World Development, 12, 10.

Lanzarotti, Mario (1992) La Corée du Sud: une sortie du sous-développement, Paris: Presses Universitaires de France.

Lijphart, Arend (1988) "The Comparable-Cases Strategy in Comparative Research", in Louis J. Cantori and Andrew Zeigler, eds., Comparative Politics in the Post-Behavioral Era, Boulder: Lynne Reinner, pp. 54-71. 
Mallon, Richard and Juan Sourrouille (1975) Economic Policymaking in a Conflict Society: the Argentine Case, Cambridge, Mass.: Harvard University Press.

[Page 165]

Journal of World-Systems Research

Masini, Jean (1986) Multinationales et pays en développement: le profit et la croissance, Paris: P.U.F

O'Donnell, Guillermo (1972) Modernizacion y autoritarismo, Buenos Aires: Paidos.

Ominami, Carlos (1986) Le Tiers Monde dans la Crise, Paris: La Découverte.

Peralta-Ramos, Monica (1992) The Political Economy of Argentina: Power and Class

Since 1930, Boulder, Colo.: Westview Press.

Ragin, Charles (1987) The Comparative Method: Moving Beyond Qualitative and Quantitative Strategies, Berkeley: University of California Press.

Ragin, Charles (1994) Constructing Social Research, Thousand Oaks: Pine Forge Press, pp. 93-98.

[Page 166]

Journal of World-Systems Research

Ranis, Peter (1992) "Market Capitalism and the Argentine Working Class", in Jacques Zylberberg and François Demers, eds., America and the Americas, Québec: Les Presses de l'Université Laval, pp. 613-629.

Ranis, Gustav and Louise Orrock (1985) "Latin American and East Asian NICs:

Development Strategies Compared", en E. Duran, ed., Latin America and the World

Recession, Cambridge: Cambridge University, pp. 48-63.

Rueschemeyer, Dietrich (1991) "Different Methods---Contradictory Results? Research on Development and Democracy", International Journal of Comparative Sociology, 32, 1 and 2, pp. 9-38.

Rueschemeyer, Dietrich and Peter Evans (1985) "The State and Economic Transformation: Toward an Analysis of the Conditions Underlying Effective Intervention", in Peter Evans, Dietrich Rueschemeyer, and Theda Skocpol, eds., Bringing the State Back In, New York: Cambridge University Press, pp. 44-77. 
Shafer, D. Michael (1994) Winners and Losers: How Sectors Shape the Developmental Prospects of States, Ithaca: Cornell University.

Smith, William C. (1990) "Democracy, Distributional Conflicts and Macroeconomic Policymaking in Argentina, 1983-89", Journal of Interamerican Studies and World Affairs 32, 2, pp. 1-42.

Stallings, Barbara (1995) "Introduction: Global Change, Regional Response", in B. Stallings, ed., Global Change, Regional Response, Cambridge: Cambridge University, pp. 1-32.

\section{APPENDIX 1: Qualitative Causal Path Analysis (QCPA)}

This alternative method of causal path analysis uses dichotomous qualitative data. Below are the definitions of the terms and the steps in the calculation of predictions for our causal model.

[Page 168]

Journal of World-Systems Research

\section{Definition of Terms}

(1) a path: a series of causal links (causal propositions) in the form of a chain (path) which ends with the dependent variable. The simplest path consists of one link.

(2) an initial value: the value (high or low) of the first independent variable of the path.

(3) the direction of the path: the sign (+ or -) of the path which indicates the effect on the dependent variable (at the end of the path) of a cause (independent variable) at the beginning of the path.

(4) the tendency of the path: the direction of the path in combination with the initial value produces a change (increase or decrease) in the dependent variable.

(5) the tendency of a policy: the tendency of the majority of the paths emanating from a policy is the tendency of a policy. 
(6) the tendency of the period: the tendency of the majority of all policies ending in the same dependent variable is the tendency of the period (for the dependent variable).

[Page 169]

Journal of World-Systems Research

\section{Steps in the Calculation of Predictions for our Causal Model}

(1) the identification of a path. One juxtaposes the numbers that designate the causal links of the chain.

Example: policy 1 is linked to growth by three different paths, 1-6-11, 1-7-8-10, and 1-79-11.

(2) the initial value. One assigns an empirical value, "high" or "low" to the variable at the beginning of the path.

Example: policy 1 "foreign investment and tariff policy" may have a "low" value, meaning that tariffs are low and foreign investment is promoted in export platforms.

(3) the direction of the path. One multiplies the signs of the links that make up a path. The multiplication rule is:

$(+)$ multiplied by $(-)=(-)$

$(+)$ multiplied by $(+)=(+)$

$(-)$ multiplied by $(-)=(+)$

[Page 170]

Journal of World-Systems Research

Example: for policy 1 (for growth in Latin America) the three paths have directions as follows:

$1-6-11:(+)(+)(+)=(+)$

1-7-8-10: $(+)(+)(-)(+)=(-)$

1-7-9-11: $(+)(+)(+)(+)=(+)$ 
(4) the tendency of the path. The direction of a path is expressed in several equivalent ways.

For a positive path: the more the $\mathrm{X}$, the more the $\mathrm{Y}$; the less the $\mathrm{X}$, the less the $\mathrm{Y}$.

For a negative path: the more the $\mathrm{X}$, the less the $\mathrm{Y}$; the less the $\mathrm{X}$, the more the $\mathrm{Y}$.

In order to determine the appropriate expression, one must refer to the initial value. If the initial value is "high", the verbal formulation begins with "The more the X". If the initial value is "low", the formulation begins with "The less the X". The remainder of the verbal formulation depends on the direction of the path. The complete formulation indicates the tendency of the dependent variable at the end of the path to increase or to decrease.

[Page 171]

Journal of World-Systems Research

Example: for policy 1 linked to growth, the first path, 1-6-11, has a positive direction and its initial value is "low". The formulation becomes: the lower the tariffs and the more the promotion of export platforms, the less the growth. The tendency here is a decrease in growth (see Figure 1).

(5) the tendency of the policy. The tendency of a policy is the tendency of the majority of all the paths linking a policy to the dependent variable.

Example: for policy 1 linked to growth, let us suppose that the initial value of all three paths is "low". Then the tendency of the first path is "decrease". The tendency of the second path is "increase" since this path has a negative direction. The tendency of the third path is "decrease" since this path has a positive direction. Now the majority of these three paths has a tendency to "decrease" so this is the tendency of policy 1.

(6) the tendency of the period. The tendency of the period is the majority of the tendencies of all the policies ending in the dependent variable during the period.

[Page 172]

Journal of World-Systems Research

Example: since we are examing five policy variables, each will have a tendency to increase or decrease growth. If three of the five, four of the five, or all five have the tendency to "increase", the majority tendency will be an "increase" in growth. When an external shock is included, the period tendency will be the majority of the six. A tie of three "increases" and three "decreases" results in a period tendency of "stability". This prediction means that there is no change in growth from the previous key period. 


\section{APPENDIX 2: Special Considerations in Some Predictions}

\section{The Influence of the three External Shocks}

During three key periods external shocks have influenced the development (growth, equality, and liberty) of Argentina and Korea. These shocks have direct impacts on two vulnerable conditions within the dependency sub-model: debt dependence and foreign exchange reserves. If each of these variables can be considered as the beginning of a causal path leading to development, then the initial value of each path will change in accordance with the characteristics of each shock. The majority tendency of the shock paths, then, is included with the five policy tendencies in determining the majority tendency for development in the key period. Applying the reasoning about the influence of external shocks already presented in the section on the causal model, below is an example of the calculation procedures.

[Page 173]

Journal of World-Systems Research

EXAMPLE. For the growth model of Korea in 1973, the external shock had two impacts: it lowered debt dependence and it raised foreign exchange reserves. There are three paths involved altogether.

Two paths from debt dependence to growth:

Path 8-10: initial value $=$ low, sign of path $=(-)(+)=(-)$, tendency of path $=$ increase

Path 9-11: initial value $=$ low, sign of path $=(+)(+)=(+)$, tendency of path $=$ decrease

One path from foreign exchange reserves to growth:

Path 10: initial value $=$ high, sign of path $=(+)$, tendency of path $=$ increase

The 1973 shock tendency is the tendency of the majority of the three path tendencies, an increase in growth.

[Page 174]

Journal of World-Systems Research 
In the discussion of "dependent associated development" in the "model" section, we noted that there were two often opposing consequences of dependence. (1) The flow of foreign direct investment (FDI) tends to increase growth in the short term. (2) The stock of FDI tends to decrease growth in the long term. Our model includes tendency (1) as path 1-6-10 and path 1-7-9-11 and tendency (2) as path 1-7-8-10. As noted in the model section, the predominance of the tendency to increase growth depends on the continuing flow of FDI, which masks the long term negative influence of accumulated foreign capital stock. In view of these considerations, when the flow of FDI is "high", the increase tendency (1) will prevail. When the flow of FDI is "low", the decrease tendency will prevail in the policy 1 tendency.

\section{Policy 2: Special Considerations on Agriculture Policy}

Agriculture policy influences the level of food dependence. The promotion of agriculture will reduce the need for food imports and/or increase the quantity of agricultural exports when food self-sufficiency has been reached. The reduction of food dependence will increase the reserves of foreign exchange because less food will be imported and/or more agricultural products will be exported. This is the meaning of link 8 . There is no such evident causal relation between food dependence and capital intensity/ industrial concentration. For this reason, link 9 will be omitted from policy 2 , leaving only one policy path: 2-8-10.

[Page 175]

Joumal of World-Systems Research

\section{The Influence of State Effectiveness}

The effectiveness of state intervention influences the formulation and implementation of all five policies. In many ways, effectiveness already is reflected in the model. In any key period, depending on changing requirements, the state may alter its policies (from high to low, or the reverse), showing "flexibility". Policy 3 is "selective" in targetting particular groups of firms with subsidies. "Promotion" versus regulation figures in the use of incentives instead of controls for foreign investment (policy 1) and agricultural production (policy 2), for example. The "coherence" of a set of policies is reflected in the majority tendency of the five policies within a key period. The prediction for each key period depends on this majority tendency.

\section{Policy 5-Growth}

The level of state effectiveness acts as a contingency which mediates the relation of public investment policy to growth. Link $5 \mathrm{G}$ in the model has three possibilities: 1 . privatization unconditionally promotes growth; 2 . expansion of state enterprises promotes growth when effectiveness is high; 3. expansion of state enterprises inhibits growth when effectivenss is low. Our reasoning is that unless public investment programs are well 
conceived and managed, they contribute little to inter-sectoral linkages or to necessary infrastructure.

[Page 176]

Journal of World-Systems Research

\section{Policy 5-Equality}

State effectiveness mediates the relation of wage policy to equality. Link $5 \mathrm{E}$ in the model has four possibilities: 1 . high wage setting promotes equality unconditionally; 2 . low wage setting reduces equality when effectiveness is high; 3 . low wage setting reduces equality when effectiveness is low and when inflation is high; 4 . low wage setting promotes equality when effectiveness is low and when inflation is low. Our reasoning is that organized labor naturally encourages high wage setting but opposes low wage setting. The state will succeed in reducing wages when it is effective. When the state's effectiveness is low it will succeed in reducing wages only when it allows a high rate of inflation to erode real wages. When the rate of inflation is low this wage- price scissors will not operate, and an ineffective state will not be able to compress wages over the opposition of organized labor.

[Page 177]

Joumal of World-Systems Research

\section{APPENDIX 3: A Prediction Form (an example)}

\section{Prediction Form for Growth in Latin America}

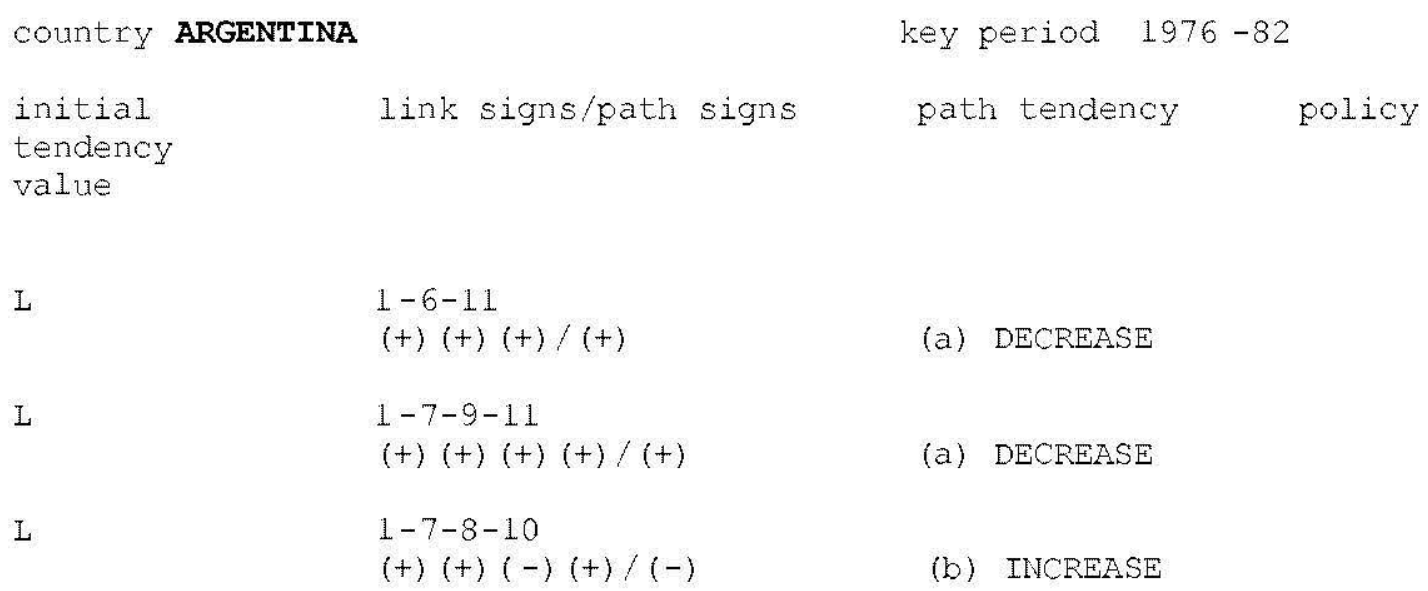




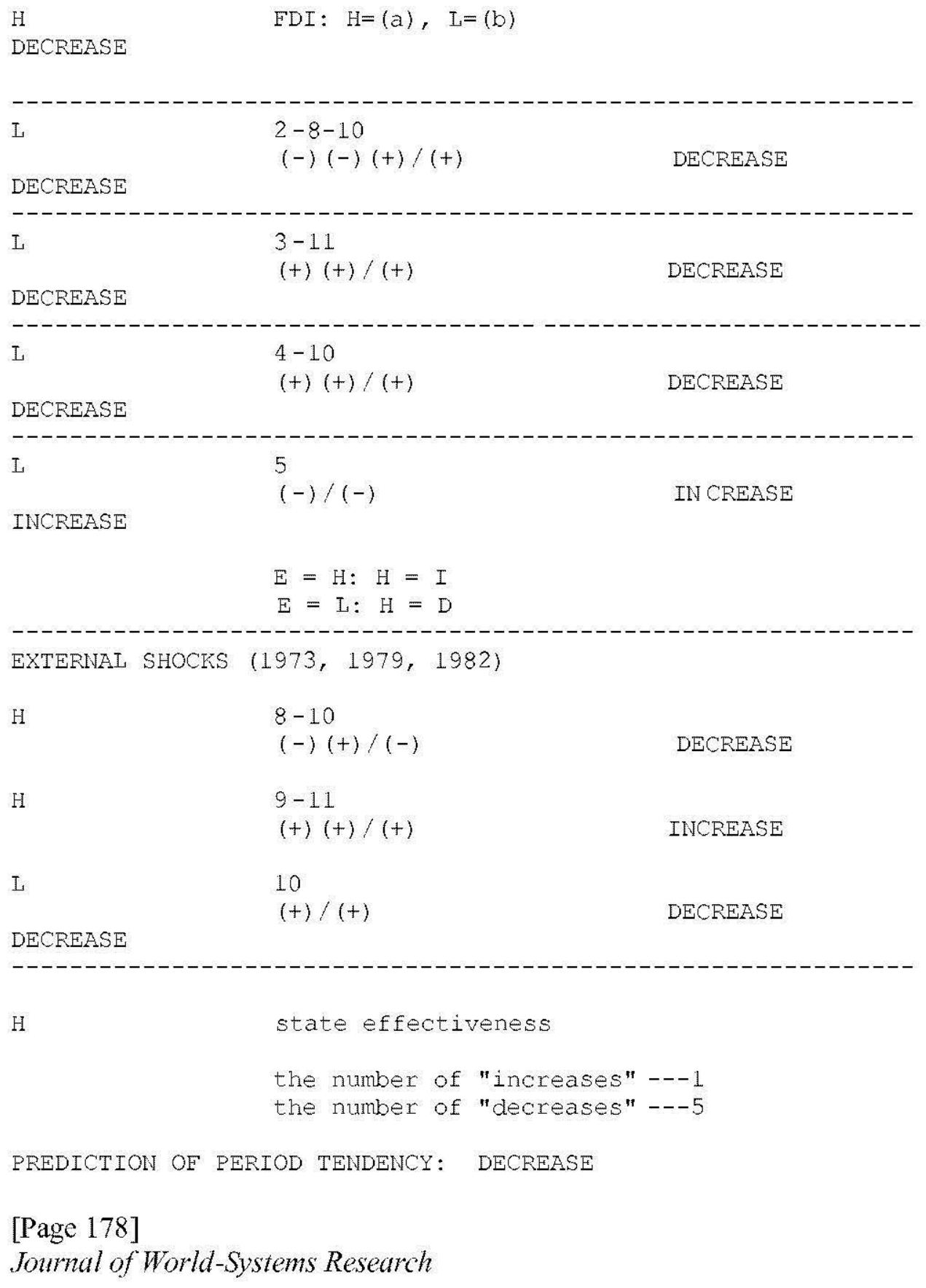

APPENDIX 4: Source References for Polic ies, FDI, and State Effectiveness ARGENTINA:

1959-62 
1. Niosi: 89,96

2. Niosi: 86; P-R: 29

3. Niosi: 91

4. Niosi: 86

5G. Niosi: 90

5E. Niosi: 98,99

5L. Niosi: 100

E.

[Page 179]

Journal of World-Systems Research

\section{$\underline{1963-65}$}

1. Niosi: 142,145

2. Niosi: 140; P-R: 29

3. Niosi: 144

4. Niosi: 145

$5 \mathrm{G}$.

5E. Niosi: 138,143

5L. Niosi: 156

E. Niosi: $142(=\mathrm{L}), 155(=\mathrm{H})$

$\underline{1966-72}$

1. Niosi: 162,166

2. Niosi: 164 (=L), $167(=H)$; Peralta-Ramos: 49-50 (=L until 1971)

3. Peralta-Ramos: 50, 58; Niosi: 166,167 
[Page 180]

Journal of World-Systems Research

4. Peralta-Ramos: 77 ; Niosi: 162,168

5G. Canitrot (1978): 9; Niosi: 162

5E. Peralta-Ramos: 50, 51, 61; Niosi: 163, 165

5L. Peralta-Ramos: 50; Niosi: 185-87

E. Niosi: $188-89$

$\underline{1973-75}$

1. Peralta-Ramos: 7

2. Peralta-Ramos: 61, 63; Canitrot (1978): 18, 39

3. Peralta-Ramos: 68 ; Canitrot (1978): 18, 30

[Page 181]

Journal of World-Systems Research

4. Peralta-Ramos: 77

5G. Canitrot (1978): 19, 25

5E. Peralta-Ramos: 64; Canitrot (1978): 16, 33, 36

5L. Peralta-Ramos: 67 (labor control by union hierarchy)

E.

$\underline{1976-82}$

1. Peralta-Ramos: 74; Canitrot (1978): 917; Peralta-Ramos: 76-77 (=H for select large firms)

2. Peralta-Ramos: $61,73-4$ (=L), 78-9 (=H); Canitrot (1980): 917,923 (=L after 1978)

3. Peralta-Ramos: 73; Canitrot (1980): 917 
[Page 182]

Journal of World-Systems Research

4. Peralta-Ramos: 75; Canitrot (1980): 924

5G. Canitrot (1994): 78 (=L)

5E. Peralta-Ramos: 72; Canitrot (1980): 917

5L. Peralta-Ramos: 72

E. Canitrot (1980): 924

1983-88

1. Peralta-Ramos: $88(=\mathrm{H}), 95,104(=\mathrm{L})$

2. Peralta-Ramos: $88,96,100(=\mathrm{H}: 1985-87)$

3. Peralta-Ramos: 88 ( $\mathrm{L}=$ subsidies to small and medium firms)

[Page 183]

Journal of World-Systems Research

4. Canitrot (1994): 84, 87; Peralta-Ramos: $110(=\mathrm{H}$ ?), 136 (=L)

5G. Peralta-Ramos: 103; Smith: 14, 23

5E. Peralta-Ramos: $98(=\mathrm{L})$

5L. Peralta-Ramos: 122

E. Peralta-Ramos: 109; Smith: 18, 33

$\underline{1989-91}$

1. initially high tariffs. After Oct. 1991: Peralta-Ramos: 148, 152 (=L); Canitrot (1994): $89(=\mathrm{L})$

2. Peralta-Ramos: 139,153

3. Peralta-Ramos: $149-52$ 
4. Canitrot (1994): 87; Peralta-Ramos: 148; in 1991 (=L) Canitrot (1994): 88-89

[Page 184]

Journal of World-Systems Research

5G. Peralta-Ramos: 148, 149; Canitrot (1994): 90-91; P. Ranis: 614

5E. Peralta-Ramos: 149, 151; Canitrot (1994): 90

$5 \mathrm{~L}$.

E.

$\underline{\text { FDI }}$

1959-70: Curhan, Davidson, and Suri: 34; Sourrouille: 21

1970-92: World Bank

1966-70: Sourrouille (mostly reinvested profits, little new inflow)

1963-65: Niosi: 146 (=L)

[Page 185]

Journal of World-Systems Research

1966-72: Niosi: $170(=\mathrm{L})$

$\underline{\text { INFLATION }}$

Mallon and Sourrouille: 13

\section{FULL REFERENCES FOR ABOVE}

Canitrot, Adolfo (1978) "La viabilidad economica de la democracia: un analisis de la experiencia peronista 1973-1976", Buenos Aires: Centro de Estudios de Estado y Sociedad.

Canitrot, Adolfo (1980) "Discipline as the Central Objective of Economic Policy: An Essay on the Economic Programme of the Argentine Government Since 1976", World Development 8, 11 (November), pp. 913-928. 
[Page 186]

Journal of World-Systems Research

Canitrot, Adolfo (1994) "Crisis and Transformation of the Argentine State (178-1992), in William C. Smith, Carlos Acuna, and Eduardo Gamarra, eds. Democracy, Markets, and Structural Reform in Latin America: Argentina, Bolivia, Brazil, Chiile, and Mexico, New Brunswick, NJ: Transaction Publishers, pp. 75-95.

Curhan, Joan, William Davidson and Rajan Suri (1977) Tracing the Multinationals: A Sourcebook on US-based Enterprises, Cambridge, Mass.: Ballinger.

Mallon, Richard and Juan Sourrouille (1975) Economic Policy-Making in a Conflict Society: The Argentine Case, Cambridge, Mass.: Harvard University Press.

Niosi, Jorge (1976) Les entrepreneurs dans la politique argentine, 1955-1973, Montreal: les Presses de l'Université du Québec.

[Page 187]

Journal of World-Systems Research

Peralta-Ramos, Monica (1992) The Political Economy of Argentina: Power and Class Since 1930, Boulder, Colo.: Westview Press.

Ranis, Peter (1992) "Market Capitalism and the Argentine Working Class", in Jacques Zylberberg and François Demers, eds., America and the Americas, Québec: Les Presses de l'Université Laval, pp. 613-629.

Smith, William C. (1990) "Democracy, Distributional Conflicts and Macroeconomic Policymaking in Argentina, 1983-89", Journal of Interamerican Studies and World Affairs 32,2 , pp. 1-42.

Sourrouille, Juan (1976) "The Impact of Transnational Enterprises on Employment and INcome: The Case of Argentina", World Employment Program Research, Working Papers, Geneva: International Labor Office.

[Page 188]

Journal of World-Systems Research

World Bank (1994) World Tables on CD-ROM. 
KOREA:

$\underline{1961-64}$

1. Yang: 244

2. Kihl and Bark: 50; Moore: 50; Hart-Landsberg: 140; Hasan \& Rao: 39-40

3. Choi: 33; Lanzarotti: 135 (1963-80)

4. Sakong: $241-2$ (adjusted exchange rate, $100=1962$ )

5G. Sakong: 79-81; H-L: 72; Song: 118

[Page 189]

Journal of World-Systems Research

$5 \mathrm{E}$.

$5 \mathrm{~L}$.

E. Shafer: $130-1$; Cheng: $158 ;$ Koo: $172-5$

$\underline{1965-72}$

1. Yang: 245-6, 254, 247; Frank, Kim, and Westphal (1975): 62

2.Kihl and Bark: 50-51; Moore: 58; Hasan: 46; Hart-Landsberg: 171-2

3. Choi: 33; Westphal (1978): 350

4. Sakong: 241-2 (adjusted exch rate)

5G. Sakong: 79-81; Hart-Landsberg: 72-3; Song: 118

[Page 190]

Journal of World-Systems Research

$5 \mathrm{E}$.

$5 \mathrm{~L}$. 
E. Shafer: 130-1; Koo: 172-5

$\underline{1973-78}$

1. Hart-Landsberg: 86-7

2. Kihl and Bark: 50, 55, 60; Moore: 59; Hasan: 160-3

3. Choi: 37; Sakong: 57, 245; Westphal (1979): 266-7

4. Kuznets: 92 (real exch. rate, $100=1972$ )

5G. Sakong: 79-81; Hart-Landsberg: 75-6; Song: 118

[Page 191]

Journal of World-Systems Research

$5 \mathrm{E}$.

$5 \mathrm{~L}$.

E. Shafer: $130-1 ;$ Koo: 172-5

$\underline{1979-81}$

1. Hart-Landsberg: 242

2. Cheng: 167; Hart-Landsberg: 257

3. Choi: 52; Sakong: 57, 245

4. Kuznets: 92 (real exch. rate)

5G. Sakong: 79-81; Song: 118

5E. Kuznets: 71, 139

[Page 192]

Journal of World-Systems Research

$5 \mathrm{~L}$. 
E. Shafer: 137-41; Hart-Landsberg: 231-2

$\underline{1982-86}$

1. Hart-Landsberg: 242

2. Hart-Landsberg: $257(=\mathrm{L}), 258$

3. Choi: 42-44; Sakong: 57,245

4. Kuznets: 92 (real exch. rate); Hart-Landsberg: 237

5G. Sakong: 79-81; Hart-Landsberg: 76; Song: 118

5E. Kuznets: 71

[Page 193]

Journal of World-Systems Research

$5 \mathrm{~L}$.

E. Shafer: 138-9; Koo: 177-8; Hart-Landsberg: 229, 231-2, 241

$\underline{1987-91}$

1. Hart-Landsberg: 243-4

2. Hart-Landsberg: 258

3. Choi: $51-2$; Sakong: 57,245

4. Kuznets: 92 (real exch. rate); Hart-Landsberg: $244(=\mathrm{H})$

5G. Sakong: 79-81

5E. Kuznets: 71; Hart-Landsberg: 252-3 (=L)

[Page 194]

Journal of World-Systems Research

5L. Hart-Landsberg: 275-80 
E. Shafer: 141; Hart-Landsberg: 241 (=L)

$\underline{\text { FDI }}$

1960-72 Jo: 5, 100; Hasan: 63-5

1970-92 World Bank

$\underline{\text { Inflation }}$

1960-88 Song: $60-61$

\section{FULL REFERENCES FOR ABOVE}

Cheng, Tun-jen (1990) "Political Regimes and Development Strategies: South Korea and Taiwan", in Gary Gereffi and Donald Wyman, eds., Manufacturing Miracles: Paths of Industrialization in Latin America and East Asia, Princeton, N.J.: Princeton University Press, pp. 139-178.

[Page 195]

Journal of World-Systems Research

Choi, Byung-Sun (1993) "Financial Policy and Big Business in Korea: The Perils of Financial Regulation", in Stephan Haggard, Chung H. Lee, and Sylvia Maxfield, eds., The Politics of Finance in Developing Countries, Ithaca, N.Y.: Cornell University Press, pp. 23-54.

Frank, Charles R., Kwang Suk Kim, and Larry Westphal (1975) South Korea: Foreign Trade Regimes and Economic Development, New York: Columbia University Press.

Hart-Landsberg, Martin (1993) The Rush to Development: Economic Change and Political Struggle in South Korea, New York: Monthly Review Press.

Hasan, Parvez and D. C. Rao (1979) Korea: Policy Issues for Long-term Development, Baltimore: Johns Hopkins University Press, for the World Bank.

[Page 196]

Journal of World-Systems Research

Jo, Sung Hwan (1976) "The Impact of Multinational Firms on Employment and Incomes: The Case Study of South Korea", World Employment Program Research, Working Paper, Geneva: International Labor Office. 
Kihl, Young Whan and Dong Suh Bark (1981) "Food Policies in a Rapidly Developing Country: The Case of South Korea, 1960-1978", Journal of Developing Areas, 16 (Oct.), pp. 47-70.

Koo, Hagen (1987) "The Interplay of State, Social Class, and World System in East Asian Development: The Cases of Korea and Taiwan", in Frederic C. Deyo, ed., The Political Economy of the New Asian Industrialism, Ithaca: Cornell University, pp. 16581.

Kuznets, Paul W. (1994) Korean Economic Development: an Interpretive Model, Westport, Conn.: Praeger.

[Page 197]

Joumal of World-Systems Research

Lanzarotti, Mario (1992) La Corée du Sud: une sortie du sous-developpement, Paris: Presses Universitaires de France.

Moore, Mick (1984) "Agriculture in Taiwan and South Korea: the Minimalist State?", IDS Bulletin, 15, 2 (April), pp. 57-64.

Sakong, Il (1993) Korea in the World Economy, Washington, D.C.: Institute for International Economics.

Shafer, D. Michael (1994) Winners and Losers: How Sectors Shape the Developmental Prospects of States, Ithaca: Cornell University.

Song, Byung-Nak (1990) The Rise of the Korean Economy, Hong Kong: Oxford University Press.

[Page 198]

Journal of World-Systems Research

Westphal, Larry (1978) "The Republic of Korea's Experience with Export-led Industrial Development", World Development, 6, 3, pp. 347-82.

Westphal, Larry (1979) "Manufacturing", in Parvez Hasan and D. C. Rao, Korea: Policy Issues forLong-Term Development, Baltimore: Johns Hopkins University Press, pp. 233 80 .

World Bank (1994) World Tables on CD ROM. 
Yang, Yoonsae (1972) "Foreign Investment in Developing Countries: Korea", in Peter Dyrsdale, ed., Direct Foreign Investment in Asia and the Pacific, Toronto: University of Toronto, pp. 242-257.

[Page 199]

Journal of World-Systems Research

\section{APPENDIX 5: Indicator Definitions and Data Sources \\ GROWTH}

Definition of Indicator

Annual percentage change in gross domestic capita per capita.

Gross domestic product at constant prices in US dollars is divided by the total population for the same year

The percentage change is cal culated as the difference between consecutive years divided by the prior year and the quotient multiplied by 100 .

\section{Sources of Data}

[Page 200]

Journal of World-Systems Research

\section{Argentina}

for 1951-64: Statistical Abstract of Latin America, 31, part 2, Table 3423, pp. 1136-37.

for 1965-92: World Bank, The East Asian Miracle, on CD Rom

\section{Korea}

for 1960-65: World Tables, 1976, Baltimore: Johns Hopkins University Press, 1976.

Economic Data Sheet 1, p. 140.

for 1965-92: World Bank, The East Asian Miracle, on CD Rom

\section{EQUALITY}


[Page 201]

Journal of World-Systems Research

\section{Definition of indicator}

The ratio of the index of the real wage per worker in manufacturing to the index of the value added per worker in manufacturing. In other words, the ratio of the average real wage index to the productivity index in manufacturing. This ratio is multiplied by 100 .

The average real wage index in manufacturing is defined as the average nominal wage divided by the cost of living index. The productivity index is defined as the value added (sectoral product) in manufacturing (in constant prices) divided by the number of salaried workers employed in manufacturing.

\section{Sources of data}

\section{Argentina}

for 1955-70: La Economia Argentina: Treinta anos en Cifras, Cuaderno 2, Buenos Aires: CIDIE, 1971.

[Page 202]

Journal of World-Systems Research

for 1970-91: World Tables on CD ROM, New York: World Bank, 1994, variables 48, 49.

\section{Korea}

for 1957-70: Charles R. Frank, Kwang Suk Kim, and Larry Westphal, Foreign Trade Regimes and Economic Development: South Korea, New York: Columbia University Press, 1975, Table 11-3, p. 222.

for 1970-91: World Tables on CD ROM, New York: World Bank, 1994, variables 48, 49.

\section{LIBERTY (Gastil and Gurr)}

\section{Definitions of two indicators}

[Page 203]

Journal of World-Systems Research 
1. Gastil: Our indicator is a combination of Gastil's measure of civil liberties and political rights. Because his measures vary from low liberty (7) to high liberty (1) we added his measures and subtracted the sum from 15. This gives a maximum of 13 (high liberty) and a minimum of 1 (low liberty).

"The Survey's understanding of freedom is broad an encompasses two sets of characteristics grouped under political rights and civil liberties. Political rights enable people to participate freely in the political process... Civil liberties are the freedoms to develop views, institutions and personal authority apart from the state". Source: Joseph E. Ryan, "The Comparative Survey of Freedom--1994-1995, Survey Methodology", Freedom in the World (1994-1995), Lanham, Md.: University Press of America, 1995, p. 5.

2. Gurr: Our indicator is a combination of Gurr's measure of democracy and autocracy. Since the two are coded independently, they may be combined. We subtract the measure of autocracy from the measure of democracy. Since each varies from 0 to 10 (maximum), our indicator varies from least liberty $(-10)$ to most liberty $(+10)$.

"There are three essential, interdependent elements of democracy... One is the presence of institutions and procedures through which citizens can express effective preferences about alternative policies and leaders, Second is the existence of institutionalized constraints on the exercise of power by the executive. Third is the guarantee of civil rights to all citizens... We do not have coded data on civil liberties. Instead our operational indicator of democracy is derived from codings of the competitiveness of political participation, the openness of executive recruitment, and constraints on the chief executive... Autocracies sharply restrict or suppress competitive political participation. Their chief executives are chosen in a regularized process of selection within the political elite, and once in office they exercise power with few institutional constraints". Source:

[Page 204]

Journal of World-Systems Research

Ted Robert Gurr, Keith Jaggers, and Will Moore, "The Transformation of the Western State: The Growth of Democracy, Autocracy, and State Power Since 1800", Studies in Comparative International Development, Spring 1990, Vol. 25, no. 1, pp.83-85.

comment It is worth noting that there is a high correlation between Gurr's and Gastil's measures, evidence of the validity of both indicators. Using the very same indicators as our study, Lane and Ersson state: "It seems justified to conclude that the Gurr and the Gastil/Freedom House indices measure the same phenomena because they are reliable in terms of different time periods as well as in different sets of countries". Source: Jan-Erik Lane and Svante Ersson, Comparative Politics: An Introduction and New Approach. Cambridge, UK: Polity Press, 1994, p. 101. 
Sources of data for the indicator based on Gastil's measure:

Argentina and Korea: 1973-1991

[Page 205]

Journal of World-Systems Research

Freedom House,"Comparative Survey of Freedom", Freedom in the World: Political Rights and Civil Liberties, various years, New York: Freedom House.

for the indicator based on Gurr's measure:

Argentina and Korea: 1955-1986

Polity II dataset, Inter-University Consortium for Political and Social Research. Data as described in Gurr, Jaggers, and Moore (1990).

[Page 206]

Journal of World-Systems Research

\section{APPENDIX 6: Data Set}

GROWTH: change in per capita gross domestic product

ARGENTINA

1955

1956

1957

1958

1959

1960

1961

1962

1963

1964

1965

1966

1967

1968

1969

1970

1971

1972

1973

$\begin{array}{ccc}1955-58 & 3 & 1955 \\ & & 1956 \\ & & 1957 \\ & & 1958 \\ 1959-62 & 0 & 1959 \\ & & 1960 \\ & & 1961 \\ & & 1962 \\ 1963-65 & 4 & 1963 \\ & & 1964 \\ 1966-72 & 2 & 1965 \\ & & 1966 \\ & & 1968 \\ & & 1969 \\ & & 1970 \\ & & 1971 \\ 1973-75 & 1 & 1972 \\ & & \end{array}$

KOREA

$1957-60$

3

0 $1961-64$

6

9. $1965-72=$

13

5

11

13

6

8

1

$13 \quad 1973-78 \quad 9$ 


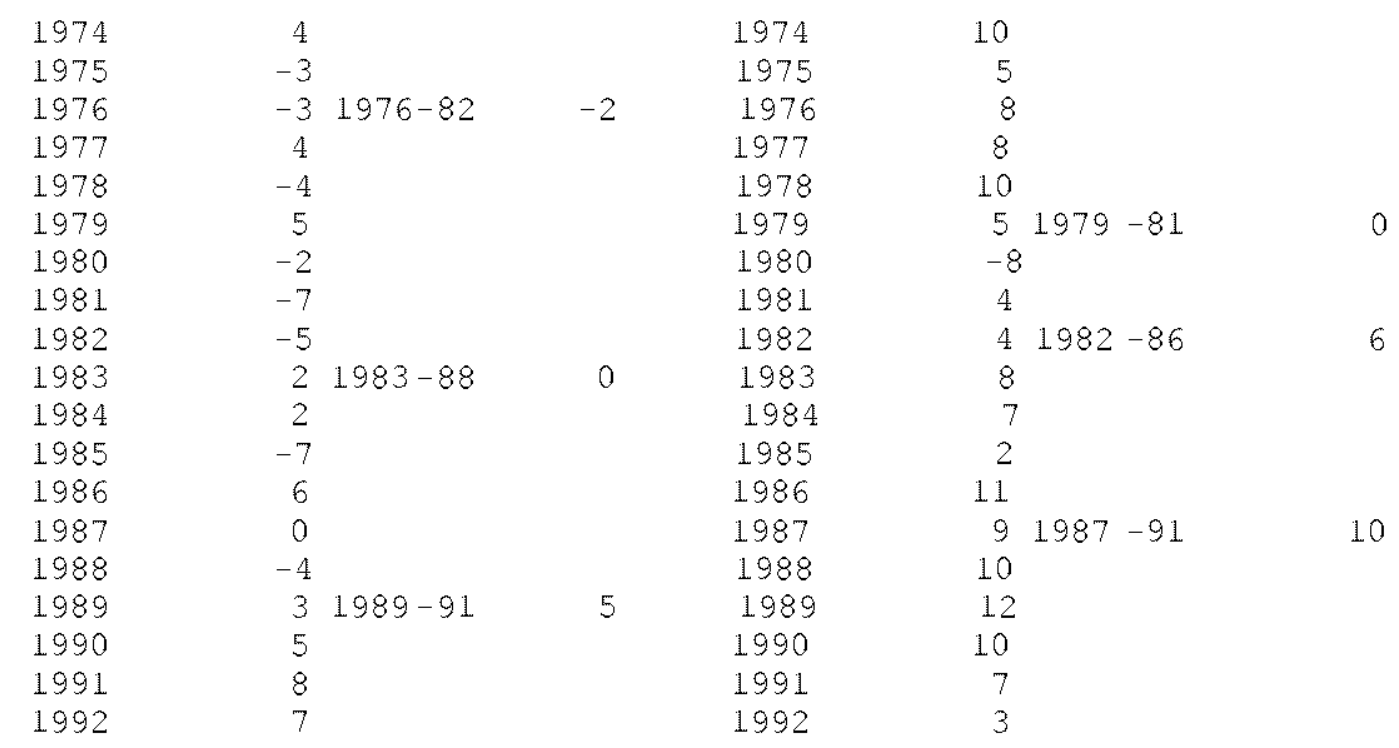

EQUALITY: ratio of real wage index to productivity index

\section{ARGENT INA}

\begin{tabular}{|c|c|c|c|c|c|c|}
\hline 1955 & 136 & $1955-58$ & 135 & 1955 & & \\
\hline 1956 & 138 & & & 1956 & & \\
\hline 1957 & 132 & & & 1957 & 118 & $1957-60$ \\
\hline 1958 & 132 & & & 1958 & 121 & \\
\hline 1959 & 107 & $1959-62$ & 101 & 1959 & 126 & \\
\hline 1960 & 100 & & & 1960 & 102 & \\
\hline 1961 & 102 & & & 1961 & 105 & $1961-64$ \\
\hline 1962 & 96 & & & 1962 & 106 & \\
\hline 1963 & 95 & $1963-65$ & 98 & 1963 & 103 & \\
\hline 1964 & 99 & & & 1964 & 95 & \\
\hline 1965 & 100 & & & 1965 & 100 & $1965-72$ \\
\hline 1966 & 101 & $1966-72$ & 93 & 1966 & 97 & \\
\hline 1967 & 104 & & & 1967 & 107 & \\
\hline 1968 & 90 & & & 1968 & 110 & \\
\hline 1969 & 86 & & & 1969 & 116 & \\
\hline 1970 & 82 & & & 1970 & 117 & \\
\hline 1971 & 96 & & & 1971 & 97 & \\
\hline 1972 & 90 & & & 1972 & 101 & \\
\hline 1973 & 96 & $1973-75$ & 123 & 1973 & 97 & $1973-78$ \\
\hline 1974 & 119 & & & 1974 & 91 & \\
\hline 1975 & 155 & & & 1975 & 91 & \\
\hline 1976 & 99 & $1976-82$ & 72 & 1976 & 99 & \\
\hline 1977 & 76 & & & 1977 & 108 & \\
\hline 1978 & 71 & & & 1978 & 118 & \\
\hline 1979 & 65 & & & 1979 & 125 & $1979-81$ \\
\hline 1980 & 64 & & & 1980 & 92 & \\
\hline 1981 & 63 & & & 1981 & 81 & \\
\hline 1982 & 66 & & & 1982 & 82 & $1982-86$ \\
\hline 1983 & 83 & $1983-88$ & 74 & 1983 & 82 & \\
\hline 1984 & 98 & & & 1984 & 82 & \\
\hline 1985 & 80 & & & 1985 & 83 & \\
\hline 1986 & 61 & & & 1986 & 82 & \\
\hline
\end{tabular}

KOREA

117

102

106

101

99

82 


\begin{tabular}{|c|c|c|c|c|}
\hline 1987 & 56 & & 1987 & $821987-91$ \\
\hline 1988 & 64 & & 1988 & 87 \\
\hline 1989 & $551989-91$ & 46 & 1989 & 94 \\
\hline 1990 & 46 & & 1990 & 87 \\
\hline 1991 & 37 & & 1991 & 86 \\
\hline 1992 & & & 1992 & 81 \\
\hline
\end{tabular}

IIBERTY: political liberties and civil rights (Gastil)

ARGENT INA

1955

1956

1957

1958

1959

1960

1961

1962

1963

1964

1965

1966

1967

1968

1969

1970

1971

1972

1973

1974

1975

1976

1977

1978

1979

1980

1981

1982

1983

1984

1985

1986

1987

1988

1989

1990

1991

1992

11

9
$1955-58$

1955

1956

1957

1958

$1959-62$

1959

1960

1961

1962

$1963-65$

$1966-72$

1963

1964

1965

1966

1967

1968

1969

1970

1971

1972

$\begin{array}{llll}6 & 1973-75 & 9 & 1973\end{array}$

$9 \quad 1976-82$

1974

1975

1976

1977

1978

1979

1980

1981

1982

$1983-88$

11

1983

1984

1985

1986

1987

1988

11

1989

1990

1991

1992
KOREA

$$
1957-60
$$

$1961-64$

$1965-72$

$4 \quad 1973-78$

5

5

$1982-86$

$1987-91$

9

LIBERTY: democracy minus autocracy (Gurr)

ARGENT INA

KOREA

1955

$\begin{array}{llll}0 & 1955-58 & -1 & 1955\end{array}$




\begin{tabular}{|c|c|c|c|c|c|c|c|}
\hline 1956 & 0 & & & 1956 & & & \\
\hline 1957 & -1 & & & 1957 & -6 & $1957-60$ & -6 \\
\hline 1958 & -1 & & & 1958 & -6 & & \\
\hline 1959 & -1 & $1959-62$ & -1 & 1959 & -6 & & \\
\hline 1960 & -1 & & & 1960 & -6 & & \\
\hline 1961 & -1 & & & 1961 & -6 & $1961-64$ & -6 \\
\hline 1962 & -1 & & & 1962 & -6 & & \\
\hline 1963 & -1 & $1963-65$ & -1 & 1963 & -6 & & \\
\hline 1964 & -1 & & & 1964 & -6 & & \\
\hline 1965 & -1 & & & 1965 & -6 & $1965-72$ & -6 \\
\hline 1966 & -8 & $1966-72$ & -8 & 1966 & -6 & & \\
\hline 1967 & -8 & & & 1967 & -6 & & \\
\hline 1968 & -8 & & & 1968 & -6 & & \\
\hline 1969 & -8 & & & 1969 & -6 & & \\
\hline 1970 & -8 & & & 1970 & -7 & & \\
\hline 1971 & -8 & & & 1971 & -7 & & \\
\hline 1972 & -8 & & & 1972 & -7 & & \\
\hline 1973 & 5 & $1973-75$ & 5 & 1973 & -7 & $1973-78$ & -7 \\
\hline 1974 & 5 & & & 1974 & -7 & & \\
\hline 1975 & 5 & & & 1975 & -7 & & \\
\hline 1976 & -8 & $1976-82$ & -7 & 1976 & -7 & & \\
\hline 1977 & -8 & & & 1977 & -7 & & \\
\hline 1978 & -8 & & & 1978 & -7 & & \\
\hline 1979 & -8 & & & 1979 & -7 & $1979-81$ & -7 \\
\hline 1980 & -8 & & & 1980 & -7 & & \\
\hline 1981 & -7 & & & 1981 & -7 & & \\
\hline 1982 & 0 & & & 1982 & -7 & $1982-86$ & -7 \\
\hline 1983 & 5 & $1983-88$ & 5 & 1983 & -7 & & \\
\hline 1984 & 5 & & & 1984 & -7 & & \\
\hline 1985 & 5 & & & 1985 & -7 & & \\
\hline 1986 & 5 & & & 1986 & -7 & & \\
\hline 1987 & & & & 1987 & & $1987-91$ & \\
\hline 1988 & & & & 1988 & & & \\
\hline 1989 & & $1989-91$ & & 1989 & & & \\
\hline 1990 & & & & 1990 & & & \\
\hline 1991 & & & & 1991 & & & \\
\hline
\end{tabular}

[Page 207]

Journal of World-Systems Research 